ARTICLE

\title{
Accessing the main-group metal formyl scaffold through CO-activation in beryllium hydride complexes
}

Terrance J. Hadlington (i) ${ }^{1 凶} \&$ Tibor Szilvási ${ }^{2}$

Carbon monoxide ( $\mathrm{CO})$ is an indispensable $\mathrm{C} 1$ building block. For decades this abundant gas has been employed in hydroformylation and Pausen-Khand catalysis, amongst many related chemistries, where a single, non-coupled CO fragment is delivered to an organic molecule. Despite this, organometallic species which react with $\mathrm{CO}$ to yield $\mathrm{C} 1$ products remain rare, and are elusive for main group metal complexes. Here, we describe a range of amidoberyllium hydride complexes, and demonstrate their reactivity towards $\mathrm{CO}$, in its monoinsertion into the $\mathrm{Be}-\mathrm{H}$ bonds of these species. The small radius of the $\mathrm{Be}^{2+}$ ion in conjunction with the non-innocent pendant phosphine moiety of the developed ligands leads to a unique beryllium formyl complex with an ylidic $\mathrm{P}_{-} \mathrm{CO}^{\mathrm{C}}$ fragment, whereby the carbon centre, remarkably, datively binds Be. This, alongside reactivity toward carbon dioxide, sheds light on the insertion chemistry of the Be-H bond, complimenting the long-known chemistry of the heavier Alkaline Earth hydrides.

\footnotetext{
${ }^{1}$ Department of Chemistry, Technische Universität München, Lichtenbergstraße 4, 85747 Garching, Germany. ${ }^{2}$ Department of Chemical and Biological

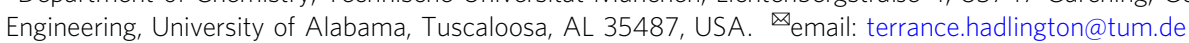


T he two naturally occurring neutral carbon oxides, $\mathrm{CO}$ and $\mathrm{CO}_{2}$, have long stood as key building blocks in chemical synthesis, most prominently so for $\mathrm{CO}$ in the Fischer-Tropsch ${ }^{1,2}$, hydroformylation ${ }^{3,4}$, and Pauson-Khand processes $^{5,6}$. Whilst the former yields higher hydrocarbons, the latter two involve the incorporation of a single $\mathrm{CO}$ molecule, as a formyl group, into unsaturated $\mathrm{C}-\mathrm{C}$ bonds. Inspired by this, the insertion chemistry of $\mathrm{CO}$ into the $\mathrm{M}-\mathrm{H}$ bond of $f$-block and early $d$-block metals is relatively well studied, though typically leading to C-C coupled products $^{7-11}$, with only a small handful of examples leading to stable $\mathrm{C} 1$ insertion products ${ }^{12-14}$. The related CO-insertion reaction in main-group hydride systems is extremely rare, the only well-defined examples derived from the group 2 metals, $\mathrm{Mg}$ and $\mathrm{Ca}$ (Fig. 1). In 2015, both the groups of Jones and Hill showed

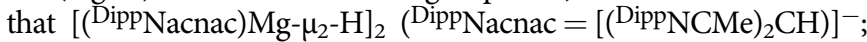
Dipp $=2,6-\mathrm{PrC}_{6} \mathrm{H}_{3}$ ) reacts with $\mathrm{CO}$ to yield the ethenediolate moiety through $\mathrm{C}-\mathrm{C}$ dimerisation of $\mathrm{CO}$, in a similar fashion to $f$ block and early $d$-block metals, whilst it was also shown by Jones et al. that employing the less bulky DepNacnac ligand rather led to $\mathrm{CO}$ trimerisation in the formation of a cyclopropanetriolate complex ${ }^{15,16}$. Hill et al. later showed that related Ca chemistry, using [(DippNacnac)Ca- $\left.\mu_{2}-\mathrm{H}\right]_{2}$, also led to ethenediolate complex formation ${ }^{17}$. In contrast to these various $\mathrm{CO}$ coupling reactions, the catalytic hydrosilylation of $\mathrm{CO}$ was achieved with both $\mathrm{Mg}$ and $\mathrm{Ca}$ complexes to exclusively yield $\mathrm{C} 1$ products ${ }^{16,17}$, despite no such products being observed in stoichiometric processes described above.

Related Be chemistry, remarkably, has yet to be explored. Still, one could hypothesise unique reactivity given the high covalent character of $\mathrm{Be}-\mathrm{X}(\mathrm{X}=\mathrm{H}$ or $\mathrm{C})$ bonds in combination with the extremely small ionic radius, and thus high charge density, of $\mathrm{Be}^{2+}$. Despite interest in the solid-state behaviour of $\mathrm{BeH}_{2}$ over the past decades, even the structure of this binary hydride has long been a point of contention and was only elucidated relatively recently 18,19 . It is perhaps then unsurprising that very little molecular chemistry of beryllium hydrides has been forthcoming, with well-defined examples of such complexes limited to one example of a tris(pyrazolyl)borate beryllium hydride complex, and three examples of NHC-stabilised methyl beryllium hydride complexes ${ }^{20-23}$. The insertion chemistry of the Be-H bond, which is now well established for $\mathrm{Mg}-\mathrm{Ba}$, is non-existent outside of isolated examples of heterocyclic ring-opening processes for $\mathrm{Be}^{21,22}$, which have been subject to computational mechanistic investigation ${ }^{24}$. This is no doubt in part due to the historically renowned toxicity of beryllium, largely in the form of the powdered element ${ }^{25,26}$, which in modern labs can be handled quite easily albeit following considerable caution and safety measures. We therefore wished to develop a reproducible route to soluble beryllium hydride complexes utilising phosphine-functionalised amido pro-ligands, ${ }^{\text {PhiP DippH }} \quad\left({ }^{\mathrm{PhiP}} \mathrm{Dipp}=\mathrm{Ph}_{2} \mathrm{PCH}_{2} \mathrm{Si}\left({ }^{\mathrm{P} P r}\right)_{2} \mathrm{~N}(\mathrm{H})\right.$ Dipp; Dipp $=2,6$ $\left.{ }^{i} \mathrm{Pr}_{2} \mathrm{C}_{6} \mathrm{H}_{3}\right),{ }^{\mathrm{PhPh}} \mathrm{DippH}\left({ }^{\mathrm{PhPh}} \mathrm{Dipp}=\mathrm{Ph}_{2} \mathrm{PCH}_{2} \mathrm{Si}(\mathrm{Ph})_{2} \mathrm{~N}(\mathrm{H}) \mathrm{Dipp}\right)$, and the novel ${ }^{\mathrm{iPPh}} \mathrm{DippH} \quad\left({ }^{\mathrm{PPPh}} \mathrm{Dipp}={ }^{\mathrm{i}} \mathrm{Pr}_{2} \mathrm{PCH}_{2} \mathrm{Si}(\mathrm{Ph})_{2} \mathrm{~N}(\mathrm{H})\right.$ Dipp), developed in our laboratories ${ }^{27}$, so as to begin to elucidate the broader reactive behaviour of molecular beryllium hydride complexes, as well as seeking non-innocent involvement of the pendant phosphine arm in our ligand systems. Herein we discuss our initial findings towards this end, in the facile access to dimeric amido-beryllium hydride complexes, and their reactivity towards $\mathrm{CO}_{2}$ and $\mathrm{CO}$. Most interestingly, the reactions of [PhiPDippBe- $\left.\mu_{2}-\mathrm{H}\right]_{2}(\mathbf{6})$ and $\left[{ }^{\mathrm{iPPh}} \mathrm{DippBe}-\mu_{2}-\mathrm{H}\right]_{2}(\mathbf{8})$ with CO proceed to yield the mono-insertion products, with no observed $\mathrm{C}-\mathrm{C}$ coupling, contrary to previous reports of related $\mathrm{Mg}$ and $\mathrm{Ca}$ chemistry. This has led to the formation of a stable beryllium formyl complex, 11, being a rare example of such a metal formyl complex derived from a molecular hydride, standing as an exciting start for reactive beryllium hydride chemistry.

\section{Results and discussion}

Our studies began with the synthesis of amido-beryllium halide complexes, 1-3, which was readily achieved by the addition of cooled toluene to a mixture of $\mathrm{BeBr}_{2} \cdot\left(\mathrm{Et}_{2} \mathrm{O}\right)_{2}$ and potassium amides PhiPDippK, ${ }^{{ }^{2} P h}$ DippK, and ${ }^{{ }^{1 P P h}}$ DippK, respectively, at low temperature (Fig. 2$)^{28}$. Slow warming led to essentially quantitative formation of the desired halide complexes as ascertained by ${ }^{31} \mathrm{P}\left\{{ }^{1} \mathrm{H}\right\}$ NMR spectroscopy. Here we note that only compound $\mathbf{1}$ was isolated, whilst $\mathbf{2}$ and $\mathbf{3}$ were generated in situ and used directly following filtration of the crude reaction mixture. We initially sought to access the beryllium hydride complexes via reaction of beryllium alkyl complexes with mild hydride sources, such as boranes and silanes, given the success of this method for Be and heavier group 2 species reported previously ${ }^{18,20,29}$. To this end, $\mathbf{1}$ was reacted with benzyl potassium in toluene to generate the beryllium benzyl complex 4 (Fig. 2). Upon reaction with an excess of pinacol borane (HBpin), some evidence for the formation of a Be-hydride was found in the HBpin-activation product, 5 (Fig. 2), which is quantitatively formed in this reaction presumably through the further reaction of the target hydride complex 6 (vide infra) with HBpin. Indeed, such ring-opening reactions for HBpin have precedent in alkaline-earth metal chemistry ${ }^{30,31}$. Initial studies regarding the reaction of benzyl complex $\mathbf{4}$ with the less reactive hydride source, phenyl silane $\left(\mathrm{PhSiH}_{3}\right)$, did not show any reaction, even after heating for extended periods of time. However, addition of catalytic quantities of potassium tert-butoxide $(\sim 0.5 \mathrm{~mol} \%)$ and heating for

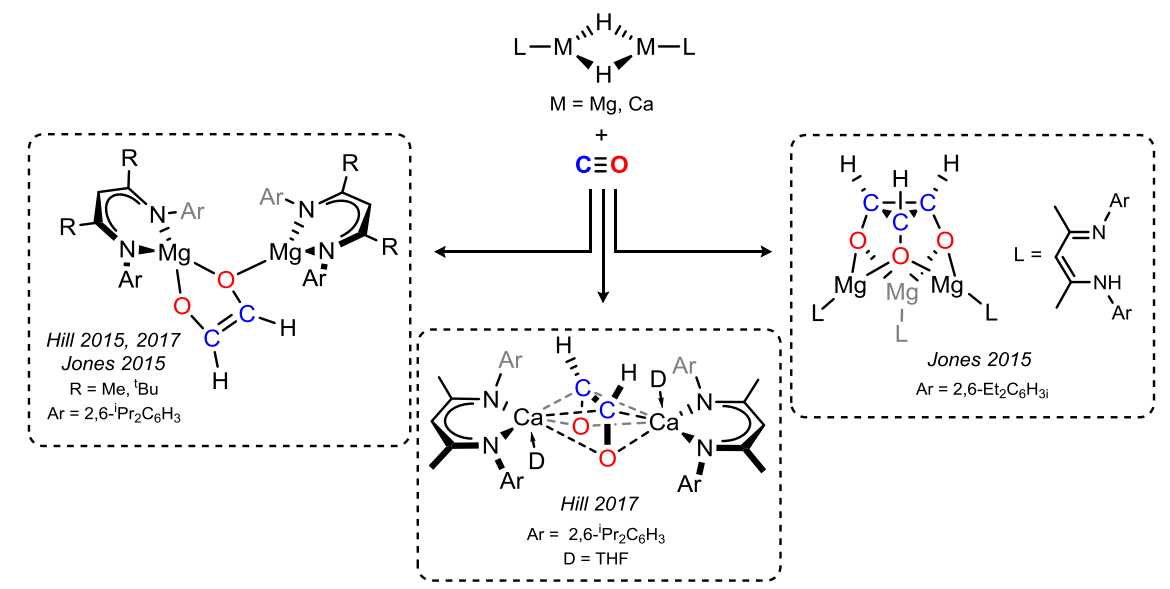

Fig. 1 CO-dimerisation and -trimerisation through metalation with Alkaline Earth hydride complexes. Reaction of molecular magnesium and calcium hydride complexes has led to either CO-dimerisation, forming the ethenediolate moiety, or trimerisation, forming the cyclopropanetriolate ligand. 
a<smiles>CCCc1cccc(CCC)c1N1CC[P](c2ccccc2)(c2ccccc2)[V]1</smiles><smiles>CCCc1cccc(C(C)C)c1N1CC[PH](c2ccccc2)(c2ccccc2)B1Br</smiles>

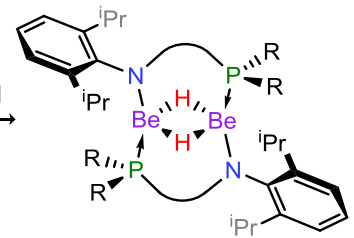

$R=P h, R^{\prime}={ }^{i} P r ; 1$

$\mathrm{R}=\mathrm{Ph}, \mathrm{R}^{\prime}=\mathrm{Ph} ; \mathbf{2}$

$\mathrm{R}=\mathrm{Ph}, \mathrm{R}^{\prime}=\mathrm{i}^{\mathrm{P}} \mathrm{P} ; 6$

$R={ }^{i} \operatorname{Pr}, R^{\prime}={ }^{i} \operatorname{Pr} ; 3$

$\mathrm{R}=\mathrm{Ph}, \mathrm{R}^{\prime}=\mathrm{Ph} ; 7$

$R={ }^{i} \operatorname{Pr}, R^{\prime}={ }^{i} P r ; 8$

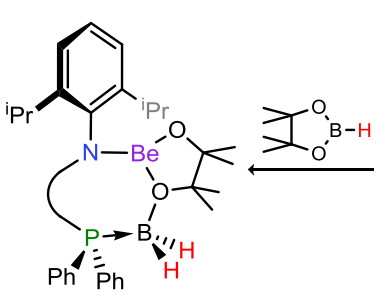

$R^{\prime}=$ 'Pr; 5

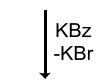

$\mathrm{KBz}$
$-\mathrm{KBr}$

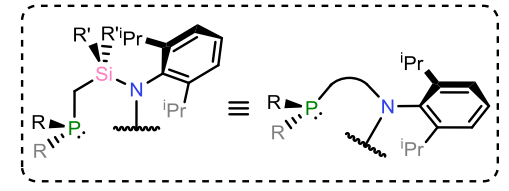

b

c
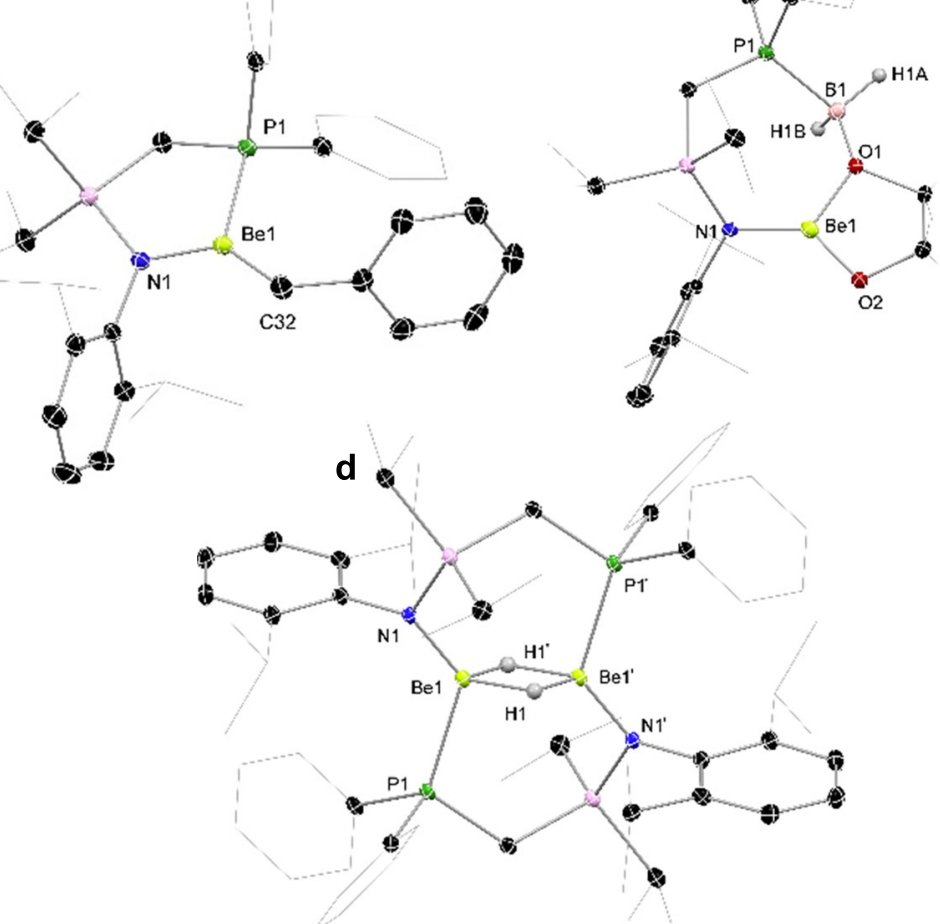

Fig. 2 Synthesis of compounds 1-8, and the X-ray crystal structures of 4-6. Beryllium hydride complexes 6-8 can be synthesised via addition of a hydrido-borate to amido-beryllium bromides, $\mathbf{1 - 3}$, or through addition of $\mathrm{PhSiH}_{3}$ to the amido-beryllium benzyl complex $\mathbf{4}$ in the presence of a strong base. Addition of pinacol borane (HBpin) to $\mathbf{4}$ leads to transient hydride formation followed by HBpin activation in 5. a Synthesis of compounds 1-8. b Solid state structure of complex 4. c Solid state structure of complex 5. d Solid state structure of complex $\mathbf{6}$. Thermal ellipsoids for 4-6 at 30\% probability. Selected distances $(\AA)$ and angles $\left(^{\circ}\right)$ for 4: Be1-C32 1.761(4); Be1-N1 1.590(3); Be1-P1 2.217(3); P1-Be1-C32 126.9(1); C32-Be1-N1 132.2(2); N1-Be1-P1 100.8(1). For 5: Be1-O1 1.633(4); Be1-O2 1.489(3); B1-O1 1.510(4); P1-B1 1.952(3); Be1-N1 1.615(3). For 6: Be1-P1 2.249(5); Be1-N1 1.623(4); Be1-Be1' 2.125(6); Be1-H1 1.43(4); Be1-H1' 1.50(3); P1-Be1-Be1' 105.1(2); N1-Be1-Be1' 128.9(3). 
$24 \mathrm{~h}$ led to conversion to one new species, as well as considerable amounts of the silylated ligand, ${ }^{\mathrm{PhiP}} \mathrm{DippN}-\mathrm{Si}(\mathrm{H})_{2} \mathrm{Ph}$. Whilst strong bases are known to lead to $\mathrm{SiH}_{4}$ formation through $\mathrm{PhSiH}_{3}$ decomposition, ${ }^{1} \mathrm{H}$ NMR spectroscopic analyses of reaction mixtures suggest the presence of $\mathrm{PhSi}(\mathrm{H})_{2} \mathrm{Bz}^{32}$. Cooling of reaction mixtures leads to the formation of extremely large colourless crystals, up to $10 \times 10 \times 5 \mathrm{~mm}$, which were ascertained to be the target beryllium hydride complex $\left[{ }^{\mathrm{PhiP}} \mathrm{DippBe}-\mu_{2}-\mathrm{H}\right]_{2}$ (6) by X-ray structural analysis (Fig. 2). Despite the monomeric nature of complexes $\mathbf{4}$ and $\mathbf{5}$ in the solid state, novel beryllium hydride complex $\mathbf{6}$ is dimeric, featuring bridging hydride ligands in keeping with the few previously reported beryllium hydride complexes ${ }^{20}$. Each Be centre sits in a 4-coordinate tetrahedral environment, the phosphine arms of the amido ligands now bridging the two beryllium centres, highlighting the flexible coordination of this ligand scaffold. The Be-Be distance $\left(d_{\mathrm{BeBe}}=2.123(6) \AA\right)$ is in keeping with the two previously reported NHC-stabilised alkyl-beryllyium hydride complexes $(\mathrm{NHC}=\mathrm{N} \text {-heterocyclic carbene })^{21,22}$. Complex $\mathbf{6}$ is poorly soluble in both apolar and polar organic solvents, and is very sparingly soluble in THF at ambient temperature, but can be dissolved in refluxing THF $\left(\sim 8 \mathrm{mg} \mathrm{mL}^{-1}\right)$. Its ${ }^{31} \mathrm{P}\left\{{ }^{1} \mathrm{H}\right\} \quad \mathrm{NMR}$ spectrum shows a major broadened peak at $\delta=-18.6 \mathrm{ppm}$, and a second minor peak at $\delta=-22.2 \mathrm{ppm}$ which we believe to be due to fluctional isomerism in solution (vide infra). Due to solubility issues ${ }^{9} \mathrm{Be}$ NMR spectroscopic data could only be recorded at high temperature, where a broad peak centred at $\delta=5.1 \mathrm{ppm}$ is observed, with a notable shoulder centred at $\delta=\sim 9 \mathrm{ppm}$. We note that, due to the quadrupolar nature of ${ }^{9} \mathrm{Be}(s=3 / 2),{ }^{9} \mathrm{Be} \mathrm{NMR}$ spectra typically give broad signals, particularly in unsymmetrical binding environments such as those in the presently described compounds. A clear signal for the Be- $H$ fragment could not be observed in the ${ }^{1} \mathrm{H}$ NMR spectrum, and indeed all signals are considerably broadened. This broadening, alongside the observation of two signals in the ${ }^{31} \mathrm{P}\left\{{ }^{1} \mathrm{H}\right\}$ and ${ }^{9} \mathrm{Be}$ NMR spectra suggests to us isomerisation of $\mathbf{6}$ in solution. Computationally, we initially investigated a monomer-dimer equilibrium using the model complex $\mathbf{6}^{\prime}$ $\left(6^{\prime}=\left[{ }^{\mathrm{PhMe} X y l B e}-\mu_{2}-\mathrm{H}\right]_{2} ; \quad \mathrm{PhMe} X y l=\left[\left(\mathrm{Ph}_{2} \mathrm{PCH}_{2} \mathrm{SiMe}_{2}\right)(\mathrm{Xyl}) \mathrm{N}\right]^{-}\right)$, which is disfavoured by $24.6 \mathrm{kcal} \mathrm{mol}^{-1}$. The non-phosphinebridged ligand-binding mode for this species, however, sits only $2.2 \mathrm{kcal} \mathrm{mol}^{-1}$ higher in energy than the observed solid-state structure (Supplementary Fig. 78), which we believe explains the described observations. X-ray powder diffractograms of powdered crystals of $\mathbf{6}$ unequivocally show a single structural phase in bulk samples of this crystalline compound (Supplementary Fig. 75), ascertaining its structural 'purity'. Further, addition of 1 equiv. of ${ }^{i P r} \mathrm{NHC}\left({ }^{\mathrm{iPr}} \mathrm{NHC}=\left[(\mathrm{Me}) \mathrm{CN}\left({ }^{\mathrm{i} P r}\right)\right]_{2} \mathrm{C}\right.$ : $)$ to suspensions of 6 in $\mathrm{D}_{8^{-}}$ THF led to the complete dissolution of the hydride complex and clean formation of a single product, showing resolution of fluctional processes in 6. This new species was found to be the NHCcoordinated monomeric Be-H complex, 9 (Fig. 3), despite the aforementioned energy barrier to monomer formation. Surprisingly, the flanking phosphine arm in $\mathbf{9}$ does not coordinate Be $\left(d_{\mathrm{BeP}}=3.579(4) \AA\right)$, likely due to the small ionic radius of this element, leading to, to the best of our knowledge, the first example of a three-coordinate beryllium hydride complex. Crystals of this low-coordinate complex are considerably more air sensitive than four-coordinate 6, bubbling vigorously even under perfluorinated oil. The ${ }^{1} \mathrm{H}$ NMR spectrum of 9 contains a clear broadened multiplet signal at $\delta=4.21 \mathrm{ppm}$ integrating to $1 \mathrm{H}$ and thus in keeping with the presence of a $\mathrm{Be}-\mathrm{H}$ moiety. The ${ }^{31} \mathrm{P}\left\{{ }^{1} \mathrm{H}\right\}$ NMR spectrum contains a signal at $\delta=-21.1 \mathrm{ppm}$, considerably sharper than that in $6(\delta=-18.6 \mathrm{ppm})$, in line with the now free phosphine arm, whilst a broad signal is observed in the ${ }^{9} \mathrm{Be}$ NMR spectrum at $\delta=14.9 \mathrm{ppm}$, indicative of a threecoordinate Be-centre ${ }^{33}$. Finally, the $\mathrm{Be}-\mathrm{H}$ stretch is clearly observed in the ATR IR spectrum of 9, with peaks at 1740 and $1800 \mathrm{~cm}^{-1}$ (Supplementary Fig. 59). We note that multiple $\mathrm{Be}-\mathrm{H}$ stretches are observed due to the presence of three independent molecules of $\mathbf{9}$ in the asymmetric unit of the X-ray crystal structure of this compound.

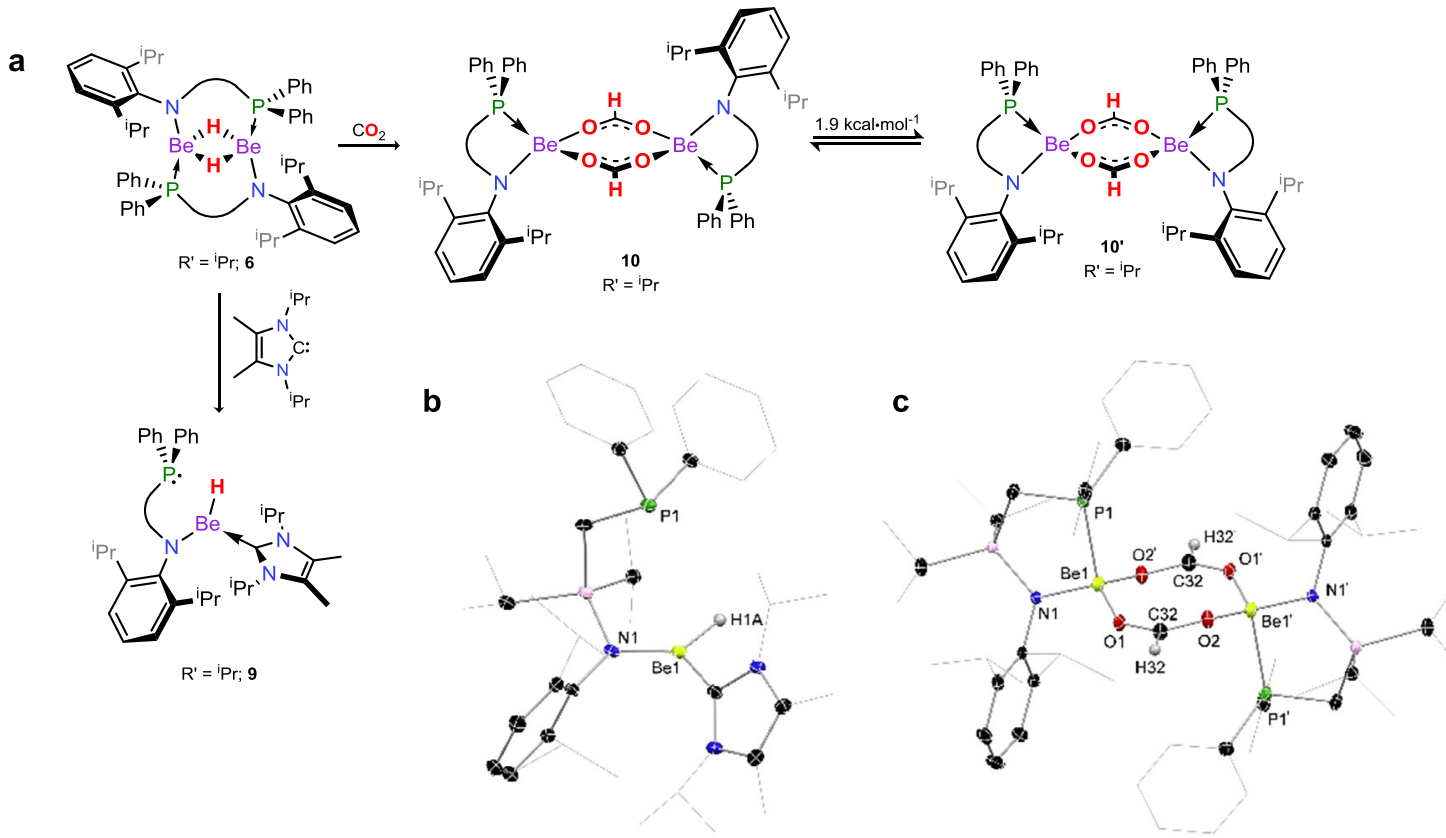

Fig. 3 Synthesis and X-ray crystal structures of compounds $\mathbf{9}$ and 10. Addition of an NHC to the dimeric amido-beryllium hydride complex $\mathbf{6}$ leads to the 3-coordinate beryllium hydride complex $\mathbf{9}$, whilst addition of $\mathrm{CO}_{2}$ to $\mathbf{8}$ leads to insertion into the $\mathrm{Be}-\mathrm{H}$ bond, forming beryllium formate $\mathbf{1 0}$, which shows structural fluctionality in solution. a Synthesis of compounds $\mathbf{9}$ and $\mathbf{1 0}$ from dimeric beryllium hydride complex $\mathbf{6}$. b Solid state structure of complex $\mathbf{9}$. c Solid state structure of complex 10. Thermal ellipsoids for $\mathbf{9}$ and $\mathbf{1 0}$ at $30 \%$ probability. Selected distance $(\AA)$ and angles $\left({ }^{\circ}\right)$ for $\mathbf{9}: \mathrm{Be} 1-\mathrm{H} 1 \mathrm{~A} 1.36(3)$; Be1-C32 1.800(5); Be1-N1 1.616(4); Be1...P1 3.537(4). For 10: Be1-O1 1.623(3); Be1-O2 1.631(3); O1-C32 1.253(3); O2-C32 1.252(3); Be1-N1 1.652(3); Be1-P1 2.282(3); O1-Be1-O2 113.5(2); O1-Be1-N1 112.5(2); O2-Be1-P1 103.9(2); N1-Be1-P1 97.9(2). 
In search for a more expedient, high-yielding route to $\mathrm{Be}-\mathrm{H}$ complexes, bromide complex $\mathbf{1}$ was reacted with $\mathrm{Li}\left[\mathrm{HB}^{\mathrm{S}} \mathrm{Bu}_{3}\right]$ in toluene at low temperature, leading to the rapid formation of copious crystalline material upon warming and standing for $1 \mathrm{~h}$ (Fig. 2). This leads to considerably improved reproducible yields of $\mathbf{6}$ of up to $90 \%$, and can be extended to complexes stabilised by differing phospine-functionalised amido ligands (viz. 2 and $\mathbf{3}$, yielding $\mathbf{7}$ and $\mathbf{8}$, respectively). Structurally, all species maintain the same ligand binding motif (Supplementary Fig. 74), bearing bridging phosphine arms and bridging hydride ligands. Compounds 7 and $\mathbf{8}$, like $\mathbf{6}$, are poorly soluble even in polar organic solvent ( $\sim 3 \mathrm{mg} \mathrm{mL}^{-1}$ in THF at ambient temperature), and show broadened signals in their ${ }^{1} \mathrm{H}$ NMR spectra, particularly so for 7 . Nevertheless, with a facile route to amido-beryllium hydride complexes established, we sought to study reactivity towards $\mathrm{CO}_{2}$ and $\mathrm{CO}$, particularly given previously reported reactivity of heavier group 2 hydrides towards these important carbon building blocks ${ }^{15,17,34,35}$. Suspensions of $\mathbf{6}$ in toluene completely dissolve over the course of $30 \mathrm{~min}$ when stirred under an atmosphere of $\mathrm{CO}_{2}$, leading to ${ }^{1} \mathrm{H}$ NMR spectra indicating the presence of two species, both of which appear to contain a formate $\mathrm{C}-H$ moiety, in a $7: 3$ ratio $(\delta=7.69$ and $7.83 \mathrm{ppm})$. Isolation of $\mathrm{X}$-ray quality crystals from these reactions mixtures allowed for structural analysis of the dimeric formate-bridged complex $\left.{ }^{\mathrm{PhiP}} \mathrm{DippBe}-\mu_{2}-\{\mathrm{OC}(\mathrm{H}) \mathrm{O}\}\right]_{2}$ (10, Fig. 3), a binding motif known for molecular main-group formate complexes. Dissolution of the crystals in $\mathrm{C}_{6} \mathrm{D}_{6}$ gave ${ }^{1} \mathrm{H}$ NMR spectra in keeping with those seen in the crude reaction mixture, with a similar ratio found for the formate signals. The bridging nature of the formate ligands is further borne out by the observation of triplets for these $C$-centres in the ${ }^{13} \mathrm{C}$ NMR spectrum $\left(\delta=166.8\right.$ and $172.0,{ }^{3} J_{\mathrm{CP}}=3.0$ and $3.1 \mathrm{~Hz}$ ), due to coupling to both ligand P-centres in this dimer. As for $\mathbf{6}$, the clear presence of two sets of signals in NMR spectra for 10 indicated fluctional structural behaviour in solution, despite powdered crystalline samples displaying a single phase in powder X-ray diffraction experiments (Supplementary Fig. 76). In this case we believe isomerism arises from the unsymmetrical nature of the ligand allowing for rotational isomer $\mathbf{1 0}^{\prime}$ (Fig. 3), which is only $1.9 \mathrm{kcal} \mathrm{mol}^{-1}$ higher in energy than 10 . As for $\mathbf{6}^{\prime}$, a monomer-dimer equilibrium was found to be unfavourable by $16.1 \mathrm{kcal} \mathrm{mol}^{-1}$, whilst the dissociation of the phosphine arms from the Be-centres, yielding three-coordinate Be, is disfavoured by $12.3 \mathrm{kcal} \mathrm{mol}^{-1}$ (see Supplementary Fig. 79). Perhaps surprisingly, this reaction represents the first example of the unassisted insertion of $\mathrm{CO}_{2}$ into the $\mathrm{M}-\mathrm{H}$ bond of a neutral group 2 hydride complex, with the closest examples involving cationic $\mathrm{Mg}$ and $\mathrm{Ca}$ complexes, and a BCF-coordinated $\left(\mathrm{BCF}=\left(\mathrm{C}_{6} \mathrm{~F}_{5}\right)_{3} \mathrm{~B}\right) \mathrm{Mg}$ and $\mathrm{Ca}$ complexes ${ }^{34}$.

We then turned our attention to the activation of carbon monoxide. Again, stirring THF-suspensions of $\mathbf{6}$ under an atmosphere of $\mathrm{CO}$ gradually led to the dissolution of this complex, albeit with longer reaction times of $16 \mathrm{~h}$, after which time one major product was observed in the ${ }^{31} \mathrm{P}$ NMR spectrum of crude reaction mixtures. Large plate-like crystals could be isolated by layering of filtered reaction mixtures with heptane, structural analysis of which revealed a remarkable dimeric beryllium formyl complex $\left[{ }^{\mathrm{PhiP}} \mathrm{DippBeC}(\mathrm{H}) \mathrm{O}\right]_{2}$ (11, Fig. 4a), by insertion of a single equivalent of carbon monoxide into each $\mathrm{Be}-\mathrm{H}$ bond. 11 a
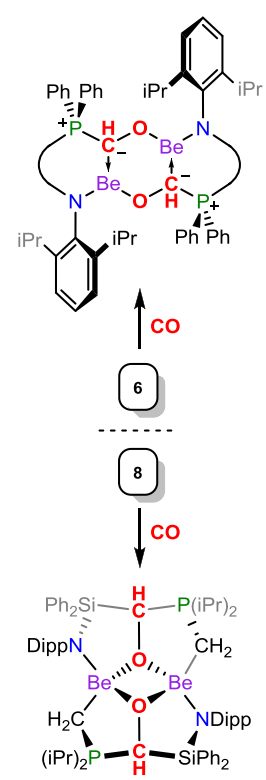

b
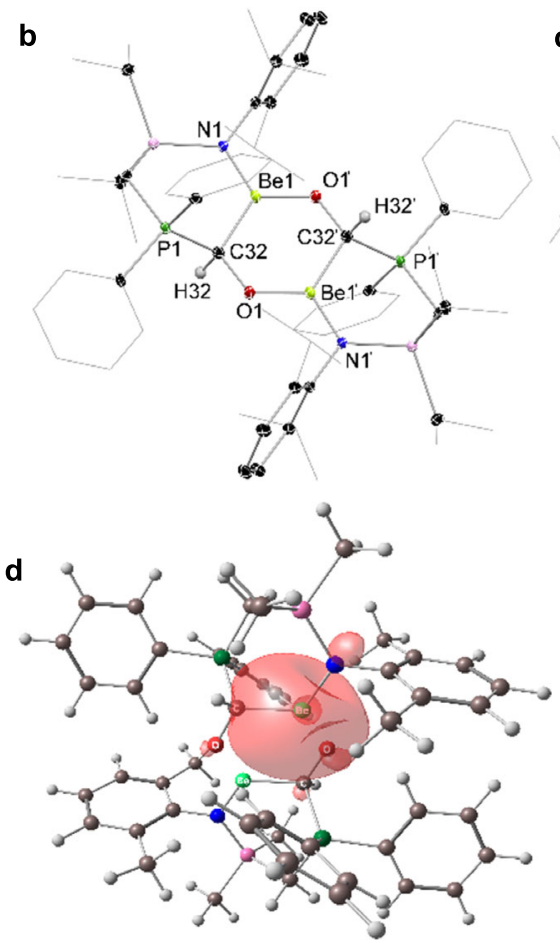

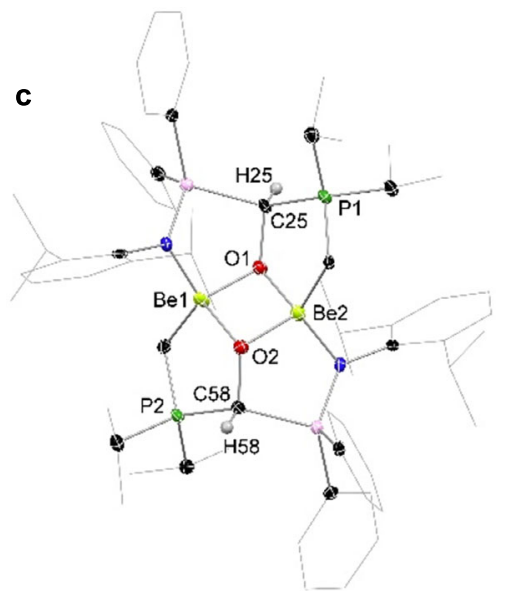

e

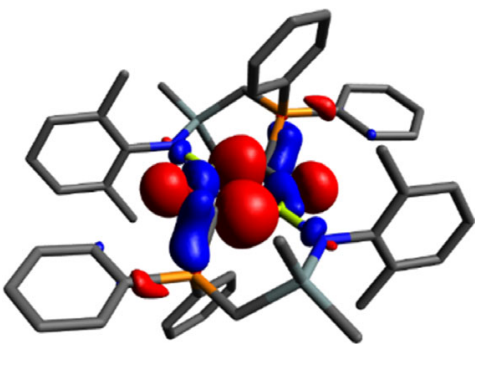

Fig. 4 Synthesis and X-ray crystal structures of compounds 11 and 12, the DFT-derived HOMO of 11moiety is (-4.04 eV), and the NBO-derived depiction of the dative $\mathbf{C} \rightarrow$ Be interaction in 11moiety is. The reaction of $\mathrm{CO}$ with hydride complex $\mathbf{6}$ leads insertion into each Be-H bond, leading to $\mathbf{1 1}$. The divergent reaction of $\mathrm{CO}$ with hydride complex $\mathbf{8}$ also proceeds through insertion into the $\mathrm{Be}-\mathrm{H}$ fragments, but follows through ligand-activation. a Synthesis of compounds $\mathbf{6}$ and $\mathbf{8}$. b Solid state structure of complex 11. c Solid state structure of complex $\mathbf{1 2}$. Thermal ellipsoids for $\mathbf{1 1}$ and $\mathbf{1 2}$ at $30 \%$ probability. Selected distances $(\AA)$ and angles $\left({ }^{\circ}\right)$ for 11: Be1-O1' 1.503(5); Be1-C32 1.807(5); Be1-N1 1.606(4); P1-C32 1.772(3); O1-C32 1.424(3); N1-Be1-C32 120.9(3); C32-Be1-O1' 119.0(3); N1-Be1-O1' 120.1(3). For 12: Be1-O1 1.695(6); Be1-O2 1.691(8); Be1-N1 1.699(8); Be1-C65 1.822(8); O1-C25 1.466(5); P1-C25 1.842(5); P1-C33 1.745(4); O1-Be1-O2 92.7(3); Be1-O1-Be2 86.0(3); O1-Be2-O2 93.6(3); Be1-O2-Be2 87.4(3). d The isolated NBOderived bonding interaction between the C-based lone-pair and Be in $\mathbf{1 1}^{\prime}$, with an energy of $81.49 \mathrm{kcal} \mathrm{mol}^{-1}$. e The HOMO of 11' (-4.04 eV). 
contains a planar central $\left[\mathrm{Be}_{2} \mathrm{C}_{2} \mathrm{O}_{2}\right]$ ring, supported by two [PhiPDipp] ligands, the phosphine-arms in which now bind the formyl carbon. The bonding in 11, whilst unprecedented, deviates from what might be expected for a dimeric formyl complex; the Be-O bonds are very short $\left(d_{\mathrm{BeO}}=1.503(5) \AA ; \bar{x}_{\mathrm{Be}-\mathrm{O}}=1.620 \AA\right)$, and the formyl C-O bonds long $\left(d_{\mathrm{CO}}=1.424(3) \AA ̊\right)$, pertaining to single bonds. The $\mathrm{Be}-\mathrm{C}$ bonds, on the other hand, are long, in the order of reported dative $\mathrm{C}-\mathrm{Be}$ bonds ${ }^{20-22}$, with the $\mathrm{C}-\mathrm{PPh}_{2}$ bond $\left(d_{\mathrm{CP}}=1.772(3) \AA\right)$ in fact slightly shorter than the remaining formal $\mathrm{C}-\mathrm{P}$ single bonds in this complex. As such, the most fitting bonding model in this species appears to be that given in Fig. 4, with a phosphonium-ylide formed between the CO-carbon and phosphine arm, formal $\mathrm{Be}-\mathrm{O}$ and $\mathrm{C}-\mathrm{O}$ single bonds, and $\mathrm{C} \rightarrow \mathrm{Be}$ dative bonding. This bonding motif has, to the best of our knowledge, not been described previously, and likely relies in part

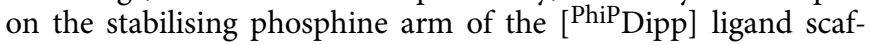
fold. A computational investigation in this bonding situation aids in corroborating the description given above. In the first instance, a natural bond orbital (NBO) analysis of the central $\left[\mathrm{Be}_{2} \mathrm{C}_{2} \mathrm{O}_{2}\right]$ moiety of $11^{\prime}$ (Table S3) indicates a high $p$-character lone electron pair on the $\mathrm{C}$ atoms, and a high $s$-character vacant orbital on each $\mathrm{Be}$, with an interaction energy of $81.49 \mathrm{kcal} \mathrm{mol}^{-1}$ between these orbitals (Fig. 4c), consistent with the $\mathrm{C} \rightarrow \mathrm{Be}$ dative bonding interpretation. Interestingly, this $\mathrm{NBO}$ analysis of the $\mathrm{Be}-\mathrm{O}$ bonds does not indicate a covalent interaction, but rather a lone pair on the $\mathrm{O}$ atom, which suggests a highly ionic interaction with the Be centre in line with the large electronegativity difference between these elements, and the calculated very low Wiberg Bond Index of 0.20 . Accordingly, the Natural Population Analysis shows +1.63 and -1.04 charge on the $\mathrm{Be}$ and $\mathrm{O}$ atoms, respectively. However, the weakness of NBO analysis for Be compounds has been noted in previous computational works because it does not consider important $2 \mathrm{p}$ atomic orbitals, and only $2 \mathrm{~s}$ atomic orbitals, thus overpredicting ionic character of Be bonds ${ }^{36-38}$. We have therefore also calculated the extended Hirshfeld method CM5 charges, the electron and laplacian of electron densities, the kinetic, potential, and total electronic energy densities, and the ellipticity at the Be-related bond critical points (BCP) of the central $\mathrm{Be}_{2} \mathrm{C}_{2} \mathrm{O}_{2}$ moiety in 11' (see Supplementary Table 4). We found that the CM5 charge shows a considerably more charged balanced, less ionic picture compared to the NPA, having Be and $\mathrm{O}$ charges of +0.63 and -0.41 , respectively. Topological analysis of the electron density shows positive values for the Laplacian of electron density at the BCP, which is a common error ${ }^{38}$, therefore we analysed the more general total electron density descriptor. The total electron density is negative at both the $\mathrm{Be}-\mathrm{C}(-0.016)$ and $\mathrm{Be}-\mathrm{O}(-0.017) \mathrm{BCPs}$, which could suggest covalent character for these interactions. Intriguingly, the ellipticity of the $\mathrm{Be}-\mathrm{C}$ bond at the BCP is 0.12 , which may suggest slight double bond character. Overall, this gives a more covalent picture for the $\mathrm{Be}-\mathrm{O}$ bonding in $\mathbf{1} \mathbf{1}^{\prime}$, and maintains a dative picture for the $\mathrm{Be}-\mathrm{C}$ bonding interactions. The relatively low-field shifted signal for the phosphorous centre in the ${ }^{31} \mathrm{P}$ NMR spectrum of $\mathbf{1 1}(\delta=10.1$ ppm) is in keeping with phosphonium-character, with the ${ }^{9} \mathrm{Be}$ NMR spectrum showing a broad signal at $\delta=10.0 \mathrm{ppm}$. The Be$C(H) \mathrm{O}$ moiety is clearly observable in both the ${ }^{1} \mathrm{H}(\delta=4.86 \mathrm{ppm}$; $\left.{ }^{2} J_{\mathrm{HP}}=12.0 \mathrm{~Hz}\right)$ and ${ }^{13} \mathrm{C}\left\{{ }^{1} \mathrm{H}\right\} \quad\left(\delta=63.3 \mathrm{ppm} ;{ }^{1} J_{\mathrm{CP}}=21.0 \mathrm{~Hz}\right)$ NMR spectra. Isomerisation to the syn-isomer of $\mathbf{1 1}$ is observed in solution, which is only $2.0 \mathrm{kcal} \mathrm{mol}^{-1}$ higher in energy than the structurally observed anti-isomer (Supplementary Fig. 80 in Supporting Information). Thus, both isomers are observed in NMR spectra of this compound. Examples of such CO monoinsertion products akin to $\mathbf{1 1}$ are very rare, and entirely unknown for main-group hydride species. The formation of $\mathbf{1 1}$ is likely driven by the very small ionic radius of $\mathrm{Be}^{2+}$ and its oxophilicity driving dimerisation, as well as the phosphine arm of the ligand allowing for the formation of the phosphonium ylide at the core of this compound. In order to expand on the scope of this reaction, hydride complex $\mathbf{8}$, featuring the novel [iPPhDipp] ligand, was reacted with CO. We were surprised to find a rather different major product arising from the reaction, that is pentacyclic 12 (Fig. 4), formed through cleavage of the ligand's $\mathrm{Si}-\mathrm{C}$ bond. This species, as 11, contains an ylidic $\mathrm{P}-\mathrm{C}$ moiety, giving further evidence for this interaction in stabilising non-COcoupled products, and highlights the potential diversity of reactive main-group/CO chemistry.

To shed further light on the formation of compound 11, the mechanism for the formation of this remarkable species was subject to a computational investigation. Calculations based on density functional theory (DFT) employing the model complex $\mathbf{6}^{\prime}$ suggest that the mechanism proceeds through two sequential insertions of a $\mathrm{CO}$ molecule into the central $\left[\mathrm{Be}_{2} \mathrm{H}_{2}\right]$ moiety, each insertion followed by an energetically favourable ligand rearrangement of the phosphine group, which migrates from Be to $\mathrm{C}$. The initial approach of the $\mathrm{CO}$ molecules to the $\mathrm{Be}-\mathrm{H}$ fragments proceeds in a side-on fashion (viz. TS1, $+16.5 \mathrm{kcal} \mathrm{mol}^{-1}$; Fig. 5), leading to an insertion product which is slightly higher in energy than $\mathbf{6}^{\prime}$ (IM1, $+3.5 \mathrm{kcal} \mathrm{mol}^{-1}$; Fig. 5). P-migration from Be to $\mathrm{C}$ (TS2 and IM2; Fig. 5), favoured by $17.3 \mathrm{kcal} \mathrm{mol}^{-1}$, would further suggest that the flanking $\mathrm{P}$-arm plays a key role in stabilising the mono-insertion product, circumventing CO-dimerisation. A similar process then proceeds at the second $\mathrm{Be}-\mathrm{H}$ moiety, with the overall reaction coordinate being exergonic by $33.4 \mathrm{kcal} \mathrm{mol}^{-1}$, in line with the ready formation of $\mathbf{1 1}$. Reactive intermediates which could lead to structure akin to $\mathbf{1 2}$ were not found, however, which insights a more in-depth investigation in the future. It is notable that this mechanism is in stark contrast to that for [(DippNacnac) $\left.\mathrm{Mg}-\mu_{2}-\mathrm{H}\right]_{2}$, which proceeds firstly through a monomer-dimer equilibrium of the hydride starting material, followed by the insertion of a single equivalent of $\mathrm{CO}$ into both $\mathrm{Mg}-\mathrm{H}$ bonds, forming $\left[(\text { DippNacnac }) \mathrm{Mg}-\mu_{2}-\left(\mathrm{OCH}_{2}\right)\right]_{2}$ as an intermediate, which can then react further with $\mathrm{CO}^{15}$. In our system, this form of intermediate is circumvented due to the chelating phosphine arm as well as the small ionic radius of $\mathrm{Be}^{2+}$, highlighting a previously unknown pathway for the functionalisation of $\mathrm{CO}$ by a metal hydride.

In conclusion, we have developed a facile synthetic method for accessing dimeric beryllium hydride species, which to date are extremely rare and, in our view, understudied. As such, we have investigated their reactivity towards the carbon oxides, $\mathrm{CO}$ and $\mathrm{CO}_{2}$. In the former case this has led to the discovery of a reactive pathway for $\mathrm{CO}$ which leads to a unique bonding motif following mono-insertion of $\mathrm{CO}$ into each $\mathrm{Be}-\mathrm{H}$ bond. Overall, this study has shed light on the high reactivity of beryllium hydride species, as well as highlighting the powerful directing effects of the employed phosphine-functionalised amido ligands we are developing in our labs. We now seek to further expand this chemistry, to further define non-innocent capacity of this ligand class.

\section{Methods}

General considerations. All experiments and manipulations were carried out under a dry oxygen free argon atmosphere using standard Schlenk techniques, or in an MBraun inert atmosphere glovebox containing an atmosphere of high purity argon. THF and diethyl ether were dried by distillation over a sodium/benzophenone mixture and stored over activated $4 \AA$ mol sieves. $\mathrm{C}_{6} \mathrm{D}_{6}$ was dried and stored over a potassium mirror. All other solvents were dried over activated $4 \AA$ mol sieves and degassed prior to use. ${ }^{P h i P} \operatorname{DippK}^{27}, \mathrm{PhPh}^{\mathrm{DippK}}{ }^{27}, \operatorname{DippN}(\mathrm{H}) \mathrm{Li}^{39}$, ${ }^{i} \mathrm{Pr}_{2} \mathrm{PCH}_{2} \mathrm{Li}^{40}, \mathrm{BeBr}_{2} \cdot\left(\mathrm{Et}_{2} \mathrm{O}\right)_{2}{ }^{28}$, and $\mathrm{BzK}^{41}$ were synthesised according to known literature procedures, and are given in the Supplementary Information. All other reagents were used as received. Solution-state NMR spectra were recorded on a Bruker AV 400 or 500 Spectrometer. Solid-state NMR spectra were recorded on a Bruker AV 300 Spectrometer. The ${ }^{1} \mathrm{H}$ and ${ }^{13} \mathrm{C}\left\{{ }^{1} \mathrm{H}\right\}$ NMR spectra were referenced to the residual solvent signals as internal standards. ${ }^{9} \mathrm{Be},{ }^{11} \mathrm{~B},{ }^{29} \mathrm{Si}$, and ${ }^{31} \mathrm{P} \mathrm{NMR}$ spectra were externally calibrated with $\mathrm{BeBr}_{2} \cdot\left(\mathrm{Et}_{2} \mathrm{O}\right)_{2}, \mathrm{BF}_{3} \cdot \mathrm{OEt}_{2}, \mathrm{SiMe}_{4}$, and $\mathrm{H}_{3} \mathrm{PO}_{4}$
} 


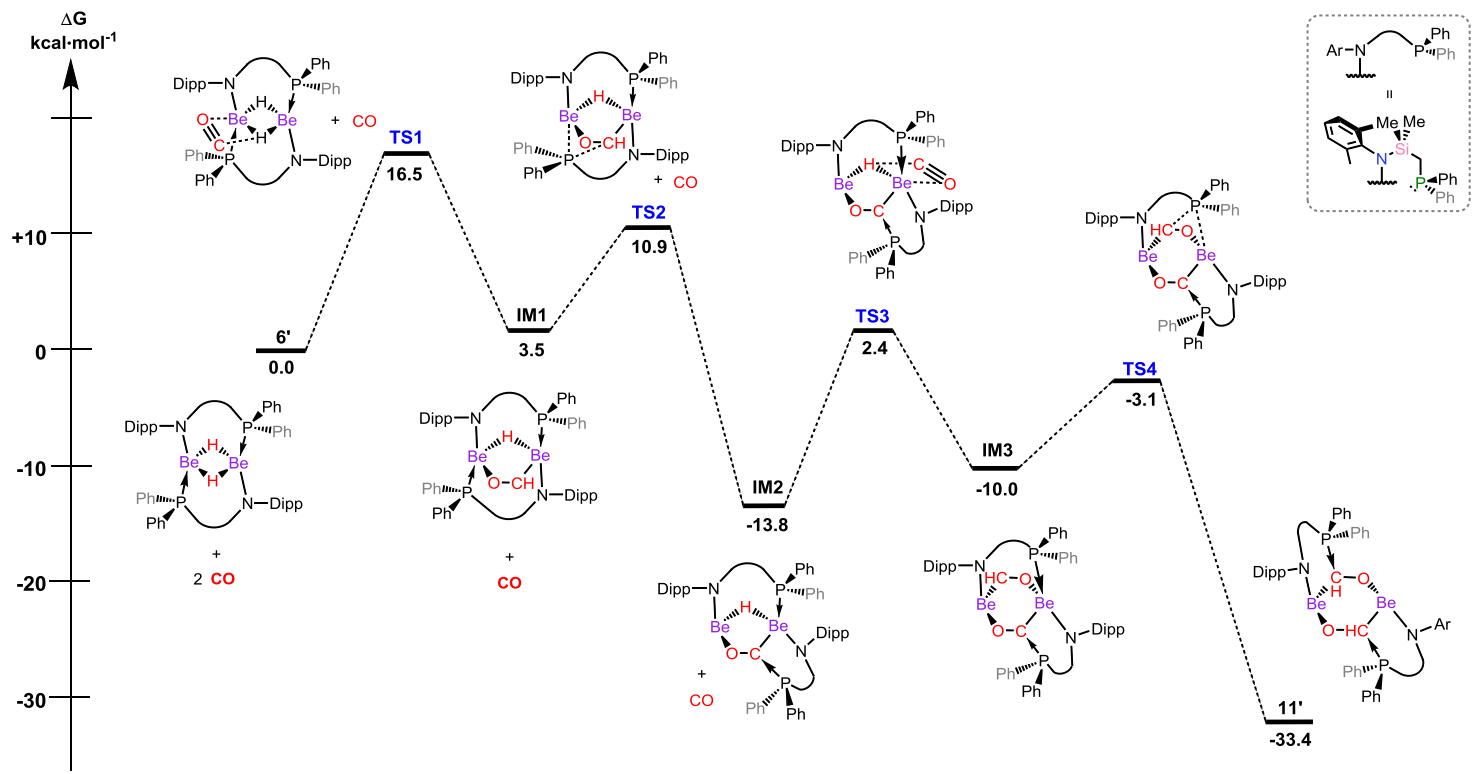

Fig. 5 Calculated free energy profile for the reaction of $\mathbf{1 1}^{\prime}$ with two equivalents of CO. The reaction proceeds via two consecutive $\mathrm{CO}$ insertion events, each beginning through side-on approach of the $\mathrm{CO}$ molecule to the Be-H moiety, and concluded by P-migration from Be to the terminal $\mathrm{CO}-$ carbon.

respectively. LIFDI MS spectra were measured at a Waters Micromass LCT TOF mass spectrometer equipped with an LIFDI ion source (LIFDI 700) from Linden $\mathrm{CMS} \mathrm{GmbH}$. The samples were dissolved in dry toluene and filtered using a syringe filter under an inert atmosphere. The TOF setup was externally calibrated using polystyrene. ESI-MS was performed on an exactive plus orbitrap spectrometer from Thermo Fischer Scientific. Infra-red spectra were measured with the Alpha FT IR from Bruker containing a platinum diamond ATR device. The compounds were measured as solids under inert conditions in a glovebox. For the ammonia activation experiments water free ammonia 5.0 was used.

Caution. Elemental beryllium, most notably as fine powders, and beryllium compounds are regarded as highly toxic and carcinogenic. A severe allergic reaction can also occur if inhaled, with the risk of causing chronic beryllium disease ${ }^{42}$. One should take care and use adequate safety measures (i.e. breathing apparatus, protective clothing, well-ventilated fume-hoods) for any manipulations involving beryllium and compounds containing this element ${ }^{26}$.

Synthesis and characterisation of new compounds. ${ }^{\text {PPh }}$ DippK. A colourless suspension of ${ }^{i} \mathrm{Pr}_{2} \mathrm{PCH}_{2} \mathrm{Li}(2.00 \mathrm{~g}, 16.13 \mathrm{mmol})$ in hexane $50 \mathrm{~mL}$ was cooled to $-78^{\circ} \mathrm{C}$, and TMEDA added $(4.8 \mathrm{~mL}, 32.26 \mathrm{mmol})$. The mixture was stirred vigorously and $\mathrm{Ph}_{2} \mathrm{SiCl}_{2}(3.4 \mathrm{~mL}, 16.13 \mathrm{mmol})$ was added. The mixture was allowed to warm to RT overnight, and all volatiles subsequently removed in vacuo, leaving a colourless oil. Solid DippN $(\mathrm{H}) \mathrm{Li}(2.94 \mathrm{~g}, 18.6 \mathrm{mmol})$ was added to the residue, and the flask cooled to $-78^{\circ} \mathrm{C}$ before the addition of THF $(50 \mathrm{~mL})$. The THF was allowed to cool for $5 \mathrm{~min}$, prior to shaking the flask by hand until the majority of the solid had dissolved, allowing free movement of the stir bar. The mixture was then stirred at $-78^{\circ} \mathrm{C}$ for $1 \mathrm{~h}$, and the cold bath removed to allow the reaction to warm to RT, giving a pale yellow solution. All volatiles were subsequently removed in vacuo and the oily residue extracted with $50 \mathrm{~mL}$ hexane, and filtered. The solvent was removed in vacuo and $\mathrm{KH}(0.84 \mathrm{~g}, 20.97 \mathrm{mmol})$ was added. After addition of $50 \mathrm{~mL}$ THF, vigorous evolution of gas was observed, and the mixture was stirred for a further $2 \mathrm{~h}$, and then allowed to settle for $16 \mathrm{~h}$. The pale yellow-brown suspension was filtered, and all volatiles were removed in vacuo. To the resulting oil hexane $(30 \mathrm{~mL})$ was added, and the mixture heated gently to $\sim 60^{\circ} \mathrm{C}$ leading to dissolution of the oil, and formation of small amounts of crystalline solid. All volatiles were removed from the mixture in vacuo, giving a solid residue which was washed twice with hexane $(15 \mathrm{~mL})$, and dried in vacuo, yielding ${ }^{\mathrm{iPPh}}$ DippNK as a free-flowing off-white crystalline powder $(6.12 \mathrm{~g}, 72 \%)$.

${ }^{1} \mathbf{H}$ NMR ( $\mathrm{D}_{8}$-THF, $400 \mathrm{MHz}, 298 \mathrm{~K}$ ): $\delta=0.91-1.03$ (overlapping d, $24 \mathrm{H}$, ${ }^{i} \mathrm{Pr}_{2} \mathrm{P}-\mathrm{CH}_{3}$ and Dipp-Pri $\left.-\mathrm{CH}_{3}\right), 1.23\left(\mathrm{~d}, 2 \mathrm{H},{ }^{2} J_{\mathrm{PH}}=4.7 \mathrm{~Hz},{ }^{\mathrm{i}} \mathrm{Pr}_{2} \mathrm{P}-\mathrm{CH}_{2}\right.$ ), 1.48 (sept of d, $\left.2 \mathrm{H},{ }^{3} J_{\mathrm{HH}}=7.2 \mathrm{~Hz},{ }^{2} J_{\mathrm{PH}}=2.5 \mathrm{~Hz},{ }^{i} \mathrm{Pr}_{2} \mathrm{P}-\mathrm{CH}\right), 3.96$ (sept, $2 \mathrm{H},{ }^{3} J_{\mathrm{HH}}=6.8 \mathrm{~Hz}$, Dipp-Pri-CH), $6.21\left(\mathrm{t}, 1 \mathrm{H},{ }^{3} \mathrm{~J}_{\mathrm{HH}}=7.4 \mathrm{~Hz}\right.$, Dipp-p-CH), $6.71\left(\mathrm{~d}, 2 \mathrm{H},{ }^{3} \mathrm{~J}_{\mathrm{HH}}=7.4 \mathrm{~Hz}\right.$, Dipp-m-CH), 7.05-7.14 (m, 6H, $\left.\mathrm{Ph}_{2} \mathrm{Si}-\mathrm{Ar}-\mathrm{CH}\right)$, 7.57-7.61 (m, 4H, $\mathrm{Ph}_{2} \mathrm{Si}-\mathrm{Ar}-\mathrm{CH}$ ).

${ }^{13} \mathrm{C}\left\{{ }^{1} \mathrm{H}\right\}$ NMR $\left(\mathrm{D}_{8}\right.$-THF, $\left.101 \mathrm{MHz}, 298 \mathrm{~K}\right): \delta=13.2\left(\mathrm{~d},{ }^{1} \mathrm{~J}_{\mathrm{CP}}=31.0 \mathrm{~Hz},{ }^{1} \mathrm{Pr}_{2} \mathrm{P}-\right.$ $\left.\mathrm{CH}_{2}-\mathrm{Si}\right), 19.6\left(\mathrm{~d},{ }^{1} J_{\mathrm{CP}}=9.6 \mathrm{~Hz},{ }^{i} \mathrm{Pr}_{2} \mathrm{P}-\mathrm{CH}_{3}\right), 21.3\left(\mathrm{~d},{ }^{1} J_{\mathrm{CP}}=15.8 \mathrm{~Hz},{ }^{1} \mathrm{Pr}_{2} \mathrm{P}-\mathrm{CH}\right)$, 25.1 (Dipp-Pri ${ }^{\mathrm{i}}-\mathrm{CH}_{3}$ ), 27.9 (Dipp-Pri $-\mathrm{CH}$ ), 112.5, 122.9, 127.3, 127.5, 135.8, 141.4, $147.7,147.8$, and $156.5($ Ar-C).
${ }^{31} \mathbf{P}\left\{{ }^{1} \mathrm{H}\right\}$ NMR $\left(\mathrm{D}_{8}\right.$-THF, $\left.162 \mathrm{MHz}, 298 \mathrm{~K}\right): \delta=-2.0\left(\mathrm{~s}, \mathrm{CH}_{2}-\mathrm{PPh}_{2}\right)$. ${ }^{29} \mathrm{Si}\left\{{ }^{1} \mathrm{H}\right\}$ NMR $\left(\mathrm{D}_{8}-\mathrm{THF}, 99 \mathrm{MHz}, 298 \mathrm{~K}\right): \delta=-47.2 \mathrm{c}\left(\mathrm{d},{ }^{2} J_{\mathrm{SiP}}=11.6 \mathrm{~Hz}\right.$, $\mathrm{SiPh}_{2}$ ).

MS/LIFDI-HRMS found (calcd.) $\mathrm{m} / z$ : 488.2852 (488.2902) for [M-K]+.

PhiP DippBeBr, 1. Solid PhiP DippK (2 g, $3.8 \mathrm{mmol})$ and $\mathrm{BeBr}_{2} \cdot\left(\mathrm{Et}_{2} \mathrm{O}\right)_{2}(1.2 \mathrm{~g}$, $3.8 \mathrm{mmol}$ ) were added to a Schlenk flask, the mixture cooled to $-78^{\circ} \mathrm{C}$ with rapid stirring, and toluene $(40 \mathrm{~mL})$ added. The suspension was stirred at low temperature for $2 \mathrm{~h}$, before being warmed to room temperature, whereby a fine precipitate had formed in place of the initial suspension, with a pale-yellow supernatant solution. To this was added $\sim 10 \mathrm{~mL}$ pentane, and the reaction filtered. Removal of all volatiles in vacuo led to a sticky residue, to which was added heptane $(10 \mathrm{~mL})$, and the flask stored at $-40^{\circ} \mathrm{C}$ overnight leading to the formation of microcrystalline solid $(1.63 \mathrm{~g}, 74 \%)$, ascertained to be pure $\mathbf{1}$.

${ }^{1} \mathrm{H}$ NMR $\left(\mathrm{C}_{6} \mathrm{D}_{6}, 400 \mathrm{MHz}, 298 \mathrm{~K}\right): \delta=0.77\left(\mathrm{~d}, 6 \mathrm{H},{ }^{3} \mathrm{~J}_{\mathrm{HH}}=7.4 \mathrm{~Hz}, \mathrm{Si}-\mathrm{Pr}^{\mathrm{i}}-\mathrm{CH}_{3}\right)$, $0.96\left(\mathrm{~d}, 6 \mathrm{H},{ }^{3} \mathrm{~J}_{\mathrm{HH}}=7.4 \mathrm{~Hz}, \mathrm{Si}-\mathrm{Pr}^{\mathrm{i}}-\mathrm{CH}_{3}\right), 1.20\left(\mathrm{~m}, 2 \mathrm{H}, \mathrm{Si}-\mathrm{Pr}^{\mathrm{i}}-\mathrm{CH}\right), 1.28(\mathrm{~d}, 6 \mathrm{H}$, $\left.{ }^{3} J_{\mathrm{HH}}=6.8 \mathrm{~Hz}, \mathrm{Dipp}-\mathrm{Pr}^{\mathrm{i}}-\mathrm{CH}_{3}\right), 1.38\left(\mathrm{~d}, 6 \mathrm{H},{ }^{3} J_{\mathrm{HH}}=6.8 \mathrm{~Hz}, \mathrm{Dipp}-\mathrm{Pr}^{\mathrm{i}}-\mathrm{CH}_{3}\right), 1.44(\mathrm{~d}$, $\left.2 \mathrm{H},{ }^{2} \mathrm{~J}_{\mathrm{PH}}=13.2 \mathrm{~Hz}, \mathrm{Ph}_{2} \mathrm{P}-\mathrm{CH}_{2}\right), 3.53$ (sept, $2 \mathrm{H},{ }^{3} \mathrm{~J}_{\mathrm{HH}}=6.8 \mathrm{~Hz}$, Dipp-Pri $-\mathrm{CH}$ ), 6.92-7.19 (m, $9 \mathrm{H}, \mathrm{Ar}-\mathrm{CH}), 7.73-7.79(\mathrm{~m}, 4 \mathrm{H}, \mathrm{Ar}-\mathrm{CH})$.

${ }^{13} \mathrm{C}\left\{{ }^{1} \mathrm{H}\right\}$ NMR $\left(\mathrm{C}_{6} \mathrm{D}_{6}, 101 \mathrm{MHz}, 298 \mathrm{~K}\right): \delta=3.1\left(\mathrm{~d},{ }^{1} \mathrm{~J}_{\mathrm{CP}}=6.4 \mathrm{~Hz}, \mathrm{Ph}_{2} \mathrm{P}-\mathrm{CH}_{2}\right)$, 13.9 and $14.0\left(\mathrm{Si}-{ }^{-} \mathrm{Pr}-\mathrm{CH}\right), 18.2$ and $18.8\left(\mathrm{Si}^{\mathrm{i}}{ }^{\mathrm{i}} \mathrm{Pr}-\mathrm{CH}_{3}\right), 23.6\left(\mathrm{Dipp}-\mathrm{Pr}^{\mathrm{i}}-\mathrm{CH}\right), 26.4$ and 28.7 (Dipp-Pri $\left.-\mathrm{CH}_{3}\right), 123.6,123.7,129.5$ (d), 131.3 (m), 131.6, 132.6, 144.6, and 145.0 (d) $(A r-C)$.

${ }^{31} \mathbf{P}\left\{{ }^{1} \mathrm{H}\right\}$ NMR $\left(\mathrm{C}_{6} \mathrm{D}_{6}, 162 \mathrm{MHz}, 298 \mathrm{~K}\right): \delta=-26.1$ (br s, $\left.\mathrm{Ph}_{2} \mathrm{P}-\mathrm{Be}\right)$.

${ }^{29} \mathrm{Si}\left\{{ }^{1} \mathrm{H}\right\}$ NMR $\left(\mathrm{C}_{6} \mathrm{D}_{6}, 99 \mathrm{MHz}, 298 \mathrm{~K}\right): \delta=9.6\left(\mathrm{~d},{ }^{2} J_{\mathrm{SiP}}=8.6 \mathrm{~Hz}, \mathrm{Si}^{\mathrm{i}} \mathrm{Pr}_{2}\right)$.

${ }^{9}$ Be NMR $\left(\mathrm{C}_{6} \mathrm{D}_{6}, 58 \mathrm{MHz}, 298 \mathrm{~K}\right), \delta=13.7$.

MS/LIFDI-HRMS found (calcd.) $\mathrm{m} / \mathrm{z}$ : 578.2155 (578.2182) for $[\mathrm{M}]^{+}$.

PhiP DippBeBz, 4. Benzyl potassium ( $290 \mathrm{mg}, 2.25 \mathrm{mmol})$ and $\mathbf{1}(1 \mathrm{~g}$, $1.73 \mathrm{mmol}$ ) were added to a Schlenk flask, and toluene $(15 \mathrm{~mL})$ added at ambient temperature. The resulting red suspension was placed in an ultrasonic bath for $15 \mathrm{~min}$, at which time only a small amount of red solid remained. The reaction mixture was filtered, concentrated to $2 \mathrm{~mL}$, and layered with heptane $(7 \mathrm{~mL})$, leading to the formation of a large amount of X-ray quality colourless crystals of 4 over the course of $24 \mathrm{~h}(630 \mathrm{mg}, 62 \%)$.

${ }^{1} \mathrm{H}$ NMR $\left(\mathrm{C}_{6} \mathrm{D}_{6}, 400 \mathrm{MHz}, 298 \mathrm{~K}\right): \delta=0.77\left(\mathrm{~d}, 6 \mathrm{H},{ }^{3} \mathrm{~J}_{\mathrm{HH}}=7.4 \mathrm{~Hz}, \mathrm{Si}^{-} \mathrm{Pr}^{\mathrm{i}}-\mathrm{CH}_{3}\right)$, $0.98\left(\mathrm{~d}, 6 \mathrm{H},{ }^{3} \mathrm{~J}_{\mathrm{HH}}=7.4 \mathrm{~Hz}, \mathrm{Si}-\mathrm{Pr}^{\mathrm{i}}-\mathrm{CH}_{3}\right), 1.21\left(\mathrm{~m}, 2 \mathrm{H}, \mathrm{Si}-\mathrm{Pr}^{\mathrm{i}}-\mathrm{CH}\right), 1.24(\mathrm{~d}, 6 \mathrm{H}$, $\left.{ }^{3} J_{\mathrm{HH}}=6.8 \mathrm{~Hz}, \mathrm{Dipp}-\mathrm{Pr}^{\mathrm{i}}-\mathrm{CH}_{3}\right), 1.38\left(\mathrm{~d}, 6 \mathrm{H},{ }^{3} J_{\mathrm{HH}}=6.8 \mathrm{~Hz}, \mathrm{Dipp}-\mathrm{Pr}^{\mathrm{i}}-\mathrm{CH}_{3}\right), 1.38(\mathrm{~d}$, $\left.2 \mathrm{H},{ }^{2} J_{\mathrm{PH}}=12.4 \mathrm{~Hz}, \mathrm{Ph}_{2} \mathrm{P}-\mathrm{CH}_{2}\right), 1.95\left(\mathrm{~d}, 2 \mathrm{H},{ }^{3} J_{\mathrm{PH}}=4.5 \mathrm{~Hz}, \mathrm{Be}-\mathrm{CH}_{2}-\mathrm{Ph}\right), 3.62(\mathrm{sept}$ $2 \mathrm{H},{ }^{3} \mathrm{~J}_{\mathrm{HH}}=6.8 \mathrm{~Hz}$, Dipp-Pri $\left.{ }^{2}-\mathrm{CH}\right), 6.87(\mathrm{~m}, 1 \mathrm{H}, \mathrm{Ar}-\mathrm{CH}), 6.97-7.03(\mathrm{~m}, 6 \mathrm{H}, \mathrm{Ar}-$ $\mathrm{CH}), 7.05-7.20(\mathrm{~m}, 11 \mathrm{H}, \mathrm{Ar}-\mathrm{CH})$.

${ }^{13} \mathbf{C}\left\{{ }^{1} \mathrm{H}\right\}$ NMR (THF- $\left.\mathrm{d}_{8}, 101 \mathrm{MHz}, 298 \mathrm{~K}\right): \delta=4.7\left(\mathrm{~d},{ }^{1} J_{\mathrm{CP}}=2.0 \mathrm{~Hz}, \mathrm{Ph}_{2} \mathrm{P}-\right.$ $\left.\mathrm{CH}_{2}\right), 14.0(\mathrm{Si}-\mathrm{Pr}-\mathrm{CH}), 18.4$ and $19.0\left(\mathrm{Si}-{ }^{\mathrm{i}} \mathrm{Pr}-\mathrm{CH}_{3}\right), 23.9$ and $26.2\left(\mathrm{Dipp}-\mathrm{Pr}^{\mathrm{i}}-\mathrm{CH}_{3}\right)$, 24.0 (br, Be- $\mathrm{CH}_{2} \mathrm{Ph}$ ), 28.4 (Dipp-Pri ${ }^{\mathrm{i}}-\mathrm{CH}$ ), 121.0, 123.2, 123.6, 125.7, 127.5, 128.6, $128.8,129.1$ (d), 129.3, 130.6, 132.5, 132.8, 133.0 (d), 144.6, 146.5 (d), and 151.5 $($ Ar-C).

${ }^{9}$ Be NMR $\left(\mathrm{C}_{6} \mathrm{D}_{6}, 58 \mathrm{MHz}, 298 \mathrm{~K}\right), \delta=17.0$.

${ }^{29} \mathrm{Si}\left\{{ }^{1} \mathrm{H}\right\}$ NMR $\left(\mathrm{C}_{6} \mathrm{D}_{6}, 99 \mathrm{MHz}, 298 \mathrm{~K}\right): \delta=8.5\left(\mathrm{~d},{ }^{2} J_{\mathrm{SiP}}=10.2 \mathrm{~Hz}, \mathrm{Si}^{-\mathrm{i}} \mathrm{Pr}_{2}\right)$. 
${ }^{31} \mathbf{P}\left\{{ }^{1} \mathrm{H}\right\}$ NMR $\left(\mathrm{C}_{6} \mathrm{D}_{6}, 162 \mathrm{MHz}, 298 \mathrm{~K}\right): \delta=-19.5$ (br s, $\left.\mathrm{Ph}_{2} \mathrm{P}-\mathrm{Be}\right)$

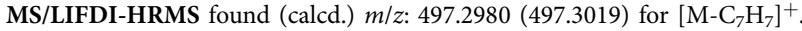

PhiP DippBe(pin) $\mathbf{B H}_{2}, 5$. To a toluene solution of $\mathbf{4}(200 \mathrm{mg}, 0.20 \mathrm{mmol})$ in toluene $(5 \mathrm{~mL})$ was added neat HBpin $(60 \mu \mathrm{L}, 0.60 \mathrm{mmol})$. The reaction mixture was shaken, and allowed to stand for $30 \mathrm{~min}$, before all volatiles were removed in vacuo. The oily residue was extracted in $\mathrm{Et}_{2} \mathrm{O}(10 \mathrm{~mL})$, filtered, and concentrated to $\sim 3 \mathrm{~mL}$. Storage of this solution at ambient temperature overnight led to the formation of a large crop of colourless crystals of $5(155 \mathrm{mg}, 62 \%)$, suitable for $\mathrm{X}$-ray crystallographic analysis.

${ }^{1}$ H NMR $\left(\mathrm{C}_{6} \mathrm{D}_{6}, 400 \mathrm{MHz}, 298 \mathrm{~K}\right): \delta=0.94\left(\mathrm{~d}, 6 \mathrm{H},{ }^{3} \mathrm{~J}_{\mathrm{HH}}=7.4 \mathrm{~Hz}, \mathrm{Si}-\mathrm{Pr}^{\mathrm{i}}-\mathrm{CH}_{3}\right)$, $1.03\left(\mathrm{~d}, 6 \mathrm{H},{ }^{3} J_{\mathrm{HH}}=7.4 \mathrm{~Hz}, \mathrm{Si}-\mathrm{Pr}^{\mathrm{i}}-\mathrm{CH}_{3}\right), 1.14$ (s, 6H, pin-Me), 1.21 (sept, $2 \mathrm{H}$, ${ }^{3} J_{\mathrm{HH}}=7.4 \mathrm{~Hz}$, Si-Pri $\left.-\mathrm{CH}\right), 1.36\left(\mathrm{~d}, 12 \mathrm{H},{ }^{3} J_{\mathrm{HH}}=6.8 \mathrm{~Hz}, \mathrm{Dipp}-\mathrm{Pr}^{\mathrm{i}}-\mathrm{CH}_{3}\right), 1.43(\mathrm{~s}, 6 \mathrm{H}$, pin- $\mathrm{Me}), 1.79\left(\mathrm{~d}, 2 \mathrm{H},{ }^{2} \mathrm{~J}_{\mathrm{PH}}=17.0 \mathrm{~Hz}, \mathrm{Ph}_{2} \mathrm{P}-\mathrm{CH}_{2}\right), 3.51\left(\mathrm{v}\right.$ br, $\left.2 \mathrm{H}, \mathrm{B} \mathrm{H}_{2}\right), 3.73$ (sept, $2 \mathrm{H},{ }^{3} \mathrm{~J}_{\mathrm{HH}}=6.8 \mathrm{~Hz}$, Dipp-Pri $\left.-\mathrm{CH}\right), 7.00-7.14(\mathrm{~m}, 9 \mathrm{H}, \mathrm{Ar}-\mathrm{CH}), 7.50-7.58(\mathrm{~m}, 4 \mathrm{H}$, Ar- $\mathrm{CH}$ )

${ }^{13} \mathrm{C}\left\{{ }^{1} \mathrm{H}\right\}$ NMR $\left(\mathrm{C}_{6} \mathrm{D}_{6}, 101 \mathrm{MHz}, 298 \mathrm{~K}\right): \delta=6.2\left(\mathrm{~d},{ }^{1} J_{\mathrm{CP}}=17.3 \mathrm{~Hz}, \mathrm{Ph}_{2} \mathrm{P}-\mathrm{CH}_{2}\right)$, 15.2 and $15.3\left(\mathrm{Si}-{ }^{\mathrm{i}} \mathrm{Pr}-\mathrm{CH}\right), 19.2$ and $19.6\left(\mathrm{Si}-{ }^{\mathrm{i}} \mathrm{Pr}-\mathrm{CH}_{3}\right), 22.7$ and $27.5\left(\right.$ pin- $\left.\mathrm{CH}_{3}\right)$, 23.7 (Dipp- $\mathrm{Pr}^{\mathrm{i}}-\mathrm{CH}_{3}$ ), 26.4 and 28.3 (Dipp- $\mathrm{Pr}^{\mathrm{i}}-\mathrm{CH}_{3}$ ), 92.3 and 92.4 (pin- $\mathrm{C}(\mathrm{Me})_{2}$ ), 123.0, 123.4, 129.1 (d), 129.8, 130.4, 131.6, 133.4 (d), 146.2, and 146.3 (Ar-C);

${ }^{9}$ Be NMR $\left(\mathrm{C}_{6} \mathrm{D}_{6}, 58 \mathrm{MHz}, 298 \mathrm{~K}\right), \delta=8.9$.

${ }^{11}$ B NMR $\left(\mathrm{C}_{6} \mathrm{D}_{6}, 43 \mathrm{MHz}, 298 \mathrm{~K}\right): \delta=-12.1$ (br, Be(pin)B $\left.\mathrm{BH}_{2}\right)$.

${ }^{29} \mathrm{Si}\left\{{ }^{1} \mathrm{H}\right\}$ NMR $\left(\mathrm{C}_{6} \mathrm{D}_{6}, 99 \mathrm{MHz}, 298 \mathrm{~K}\right): \delta=-3.0$.

${ }^{31} \mathbf{P}\left\{{ }^{1} \mathrm{H}\right\}$ NMR $\left(\mathrm{C}_{6} \mathrm{D}_{6}, 162 \mathrm{MHz}, 298 \mathrm{~K}\right): \delta=-0.9\left(\mathrm{~s}, \mathrm{Ph}_{2} \mathrm{P}-\mathrm{Be}\right)$.

IR, $v \mathrm{~cm}^{-1}$ (ATR): $2340,2385,2440(B-H)$.

MS/LIFDI-HRMS found (calcd.) $\mathrm{m} / \mathrm{z}: 626.4085$ (626.4111) for $[\mathrm{M}]^{+}$

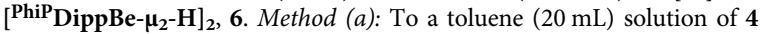
( $500 \mathrm{mg}, 0.85 \mathrm{mmol}$ ) was added $\mathrm{KO} \mathrm{B}^{\mathrm{B}} \mathrm{Bu}(\sim 1 \mathrm{mg})$ and $\mathrm{PhSiH}_{3}(0.52 \mathrm{~mL}, 4.25 \mathrm{mmol})$. The pale-yellow solution was heated to $65^{\circ} \mathrm{C}$ for $18 \mathrm{~h}$, at which stage ${ }^{31} \mathrm{P}$ NMR spectroscopic analysis indicated that all starting material had been consumed. Upon cooling the reaction mixture to ambient temperature large colourless crystals of hydride complex 6 formed (125 mg, 30\%), which were suitable for X-ray crystallographic analysis.

Method (b): A solution of $1(1 \mathrm{~g}, 1.73 \mathrm{mmol})$ in tolene $(40 \mathrm{~mL})$ was cooled without stirring, to $-78^{\circ} \mathrm{C}$. A THF solution of $\mathrm{L}$-selectride $(2.08 \mathrm{~mL}, 1 \mathrm{M})$ was then rapidly added, and the solution shaken whilst cold for a few seconds. The cold bath was then removed, allowed the reaction to reach room temperature. After standing for $1 \mathrm{~h}$ copious amounts of colourless crystalline solid had formed. Decanting the solution, washing with pentane $(10 \mathrm{~mL})$, and drying under vacuum afforded 6 (790 mg, 92\%) as an analytically pure crystalline solid.

${ }^{1} \mathrm{H}$ NMR $\left(\mathrm{D}_{8}\right.$-THF, $\left.400 \mathrm{MHz}, 338 \mathrm{~K}\right): \delta=0.50-0.75\left(\mathrm{br}, 9 \mathrm{H}\right.$, Dipp-Pri $-\mathrm{CH}_{3}$ and Si-Pri- $\left.\mathrm{CH}_{3}\right), 0.77-1.48$ (br, 17H, Dipp-Pri-CH ${ }_{3}$, Si-Pri- $\mathrm{CH}_{3}$, and $\left.\mathrm{Si}-\mathrm{Pr}{ }^{\mathrm{i}}-\mathrm{CH}\right), 1.67$ (br, 2H, Ph 2 P-CH $), 3.81$ (br, 3H, Be-H, and Dipp-Pri $\left.{ }^{\mathrm{i}}-\mathrm{CH}\right), 6.86(\mathrm{br}, 3 \mathrm{H}, \mathrm{Ar}-\mathrm{CH}$ ), 7.12-7.32 (br m, $6 \mathrm{H}, \mathrm{Ar}-\mathrm{CH}$ ), 7.36-7.70 (br m, 4H, Ar-CH).

${ }^{9}$ Be NMR $\left(\mathrm{D}_{8}\right.$-THF, $\left.58 \mathrm{MHz}, 333 \mathrm{~K}\right), \delta=5.1\left(\left[{ }^{\mathrm{PhiP}} \mathrm{DippBeH}\right]_{2}\right)$, and 9.4 (PhiP DippBeH).

${ }^{31} \mathbf{P}\left\{{ }^{1} \mathbf{H}\right\}$ NMR $\left(\mathrm{D}_{8}-\mathrm{THF}, 162 \mathrm{MHz}, 333 \mathrm{~K}\right): \delta=-17.8$ (br s, $\left[{ }^{\mathrm{PhiP}} \mathrm{DippBeH}\right]_{2}$, $\mathrm{Ph}_{2} \mathrm{P}-\mathrm{Be}$ ), and -22.2 (br s, ${ }^{\text {PhiP }}$ DippBeH, $\mathrm{Ph}_{2} \mathrm{P}-\mathrm{Be}$ ).

MS/LIFDI-HRMS found (calcd.) $\mathrm{m} / z$ : 996.6086 (996.6199) for $[\mathrm{M}]^{+}$

N.B. The poor solubility as well the broadening of signals due to fluxional solution processes of $\mathbf{6}$, even at high temperatures, precluded the collection of meaningful ${ }^{13} \mathrm{C}\left\{{ }^{1} \mathrm{H}\right\}$ and ${ }^{29} \mathrm{Si}\left\{{ }^{1} \mathrm{H}\right\}$ NMR spectra of this species.

$\left[{ }^{\mathrm{PhPh}} \text { DippBe- } \mu_{2}-\mathrm{H}\right]_{2}$, 7. Solid ${ }^{\mathrm{PhPh}}$ DippNK $(1 \mathrm{~g}, 1.68 \mathrm{mmol})$ and $\mathrm{BeBr}_{2} \cdot\left(\mathrm{Et}_{2} \mathrm{O}\right)_{2}$ $\left(530 \mathrm{mg}, 1.68 \mathrm{mmol}\right.$ ) were added to a Schlenk flask, the mixture cooled to $-78^{\circ} \mathrm{C}$ with rapid stirring, and toluene $(25 \mathrm{~mL})$ added. The suspension was stirred at low temperature for $2 \mathrm{~h}$, before being warmed to room temperature, whereby a fine precipitate had formed in place of the initial suspension, with a pale yellow supernatant solution. To this was added $\sim 10 \mathrm{~mL}$ pentane, and the reaction filtered. The filtrate was cooled to $-78^{\circ} \mathrm{C}$, without stirring, and a THF solution of $\mathrm{L}-$ Selectride $(2.02 \mathrm{~mL}, 1 \mathrm{M})$ was added. The mixture was briefly shaken, the cold bath removed, and the reaction warmed to ambient temperature. After standing for $1 \mathrm{~h}$ a large crop of colourless crystals had formed, which were isolated by filtration, washed with pentane $(5 \mathrm{~mL})$, and dried under vacuum to afford $7(810 \mathrm{mg}, 85 \%)$.

${ }^{1} \mathrm{H}$ NMR (D ${ }_{8}$-THF, $400 \mathrm{MHz}, 298 \mathrm{~K}$ ): $\delta=0.34\left(\mathrm{v}\right.$ br, $12 \mathrm{H}$, Dipp-Pri-CH ${ }_{3}$ ), 0.54 (v br, 9H, Dipp-Pri- $\mathrm{CH}_{3}$ ), 0.87 (br m, 3H, Dipp- $\left.\mathrm{Pr}^{\mathrm{i}}-\mathrm{CH}_{3}\right), 1.29$ (m, 2H, $\mathrm{Ph}_{2} \mathrm{P}-\mathrm{CH}_{2}$ ), $2.13\left(\mathrm{~m}, 2 \mathrm{H},{ }^{3} \mathrm{~J}_{\mathrm{HH}}=6.8 \mathrm{~Hz}, \mathrm{Ph}_{2} \mathrm{P}-\mathrm{CH}_{2}\right), 3.84\left(\mathrm{~m}, 2 \mathrm{H}\right.$ and $2 \mathrm{H}, \mathrm{Dipp}-\mathrm{Pr}^{\mathrm{i}}-\mathrm{CH}$ and Be$H$ ), 4.17 (br, 2H, Dipp-Pri $-\mathrm{CH}$ ), 6.85-7.47 (v br, 46H, Ar-CH).

${ }^{9}$ Be NMR (D - THF, $\left.58 \mathrm{MHz}, 298 \mathrm{~K}\right), \delta=5.3$.

${ }^{31} \mathbf{P}\left\{{ }^{1} \mathrm{H}\right\}$ NMR $\left(\mathrm{D}_{8}\right.$-THF, $\left.162 \mathrm{MHz}, 298 \mathrm{~K}\right): \delta=-16.4$ (br s, $\mathrm{Ph}_{2} \mathrm{P}$-Be).

MS/LIFDI-HRMS found (calcd.) $\mathrm{m} / z$ : 1132.5518 (1132.5573) for $[\mathrm{M}]^{+}$

N.B. The poor solubility as well the broadening of signals in the NMR spectra of 7 precluded the acquisition of meaningful ${ }^{13} \mathrm{C}\left\{{ }^{1} \mathrm{H}\right\}$ and ${ }^{29} \mathrm{Si}\left\{{ }^{1} \mathrm{H}\right\}$ spectra for this species.

$\left[{ }^{i P P h} \text { DippBe- } \boldsymbol{\mu}_{2}-\mathbf{H}\right]_{2}, 8$. The procedure for the synthesis of 7 was used, with ${ }^{i P P h}$ DippNK (500 mg, $\left.0.95 \mathrm{mmol}\right), \mathrm{BeBr}_{2} \cdot\left(\mathrm{Et}_{2} \mathrm{O}\right)_{2}(300 \mathrm{mg}, 0.95 \mathrm{mmol})$, and Lselectride $(1.14 \mathrm{~mL}, 1 \mathrm{M}$ in THF). Compound $\mathbf{8}$ was isolated as large colourless crystals suitable for X-ray crystallographic analysis $(370 \mathrm{mg}, 78 \%)$.

${ }^{1} \mathrm{H}$ NMR (D $-\mathrm{THF}, 400 \mathrm{MHz}, 338 \mathrm{~K}$ ): $\delta=-0.02\left(\mathrm{br} \mathrm{m}, 6 \mathrm{H}, \mathrm{P}-\mathrm{Pr}^{\mathrm{i}}-\mathrm{CH}_{3}\right), 0.46$ (br m, 6H, P-Pri $\left.-\mathrm{CH}_{3}\right), 0.49\left(\mathrm{~d}, 6 \mathrm{H},{ }^{3} \mathrm{~J}_{\mathrm{HH}}=6.8 \mathrm{~Hz}, \mathrm{Dipp}-\mathrm{Pr}^{\mathrm{i}}-\mathrm{CH}_{3}\right), 0.69(\mathrm{~d}, 6 \mathrm{H}$,
${ }^{3} J_{\mathrm{HH}}=6.8 \mathrm{~Hz}$, Dipp-Pri $\left.-\mathrm{CH}_{3}\right), 0.86$ (m, 2H, P-Pri $\left.{ }^{\mathrm{i}} \mathrm{CH}\right), 1.07$ (br m, 6H, P-Pr ${ }^{\mathrm{i}}-$ $\left.\mathrm{CH}_{3}\right), 1.19\left(\mathrm{~m}, 12 \mathrm{H}, \mathrm{Dipp}-\mathrm{Pr}^{\mathrm{i}}-\mathrm{CH}_{3}\right), 1.53$ (br m, 6H and 4H, P-Pri $-\mathrm{CH}_{3}$ and $\mathrm{iPr}_{2}-$ $\mathrm{CH}_{2}$ ), 2.17 (br sept, 2H, Dipp-Pri-CH), 3.69 (br m, $2 \mathrm{H}$ and $2 \mathrm{H}, \mathrm{P}-\mathrm{Pr}^{\mathrm{i}} \mathrm{-}-\mathrm{CH}$ and $\mathrm{Be}-$ H), 4.08 (sept, $2 \mathrm{H},{ }^{3} \mathrm{~J}_{\mathrm{HH}}=6.8 \mathrm{~Hz}$, Dipp-Pri-CH), 6.87 (m, 4H, Ar-CH), 6.91-6.97 (m, $10 \mathrm{H}, \mathrm{Ar}-\mathrm{CH}$ ), 7.05-7.20 (m, 8H, Ar-CH), 7.90 (m, 4H, Ar-CH).

${ }^{13} \mathbf{C}\left\{{ }^{1} \mathbf{H}\right\}$ NMR $\left(\mathrm{D}_{8}\right.$-THF, $\left.101 \mathrm{MHz}, 298 \mathrm{~K}\right): \delta=4.9,17.1,17.5$ and $18.2\left(\mathrm{P}-\mathrm{Pr}^{\mathrm{i}}-\right.$ $\mathrm{CH}_{3}$ ), 21.7 and 23.9 (m, P-Pri $\left.-\mathrm{CH}\right), 20.3,24.5,26.2$ and 27.5 (Dipp- $\left.{ }^{\mathrm{i} P r}-\mathrm{CH}_{3}\right), 28.5$ and 28.6 (Dipp-i ${ }^{\mathrm{P} r}$ - $\mathrm{CH}$ ), 123.1, 124.1, 125.1, 127.7 (d), 129.2 (d), 136.5, 137.2, $142.2,146.2,148.1$, and $152.5(A r-C)$.

${ }^{9}$ Be NMR ( $\mathrm{D}_{8}$-THF, $\left.58 \mathrm{MHz}, 338 \mathrm{~K}\right), \delta=2.8$.

${ }^{31} \mathbf{P}\left\{{ }^{1} \mathbf{H}\right\}$ NMR (D - THF, $\left.162 \mathrm{MHz}, 338 \mathrm{~K}\right): \delta=-6.9$ (br s, $\left.{ }^{1} \mathrm{Pr}_{2} \mathrm{P}-\mathrm{Be}\right)$.

MS/LIFDI-HRMS found (calcd.) $\mathrm{m} / z$ : 996.6129 (996.6199) for $[\mathrm{M}]^{+}$.

PhiP DippBeH. ${ }^{\text {iPr }}$ NHC, 9. Solid 6 ( $\left.150 \mathrm{mg}, 0.30 \mathrm{mmol}\right)$ and ${ }^{\mathrm{iPr}} \mathrm{NHC}(55 \mathrm{mg}$, $0.30 \mathrm{mmol}$ ) were mixed in a Schlenk flask, and toluene $(5 \mathrm{~mL})$ added. Stirring the suspension for $5 \mathrm{~min}$ led to dissolution of the suspension, at which point all volatiles were remove in vacuo. The residue was extracted in pentane $(10 \mathrm{~mL})$, filtered, and the resulting solution concentrated to $2 \mathrm{~mL}$. Storage at $-40^{\circ} \mathrm{C}$ for 1 week led to the formation of colourless crystals of $9(85 \mathrm{mg}, 43 \%)$, suitable for $\mathrm{X}$-ray crystallographic analysis.

${ }^{1} \mathbf{H}$ NMR $\left(\mathrm{C}_{6} \mathrm{D}_{6}, 400 \mathrm{MHz}, 298 \mathrm{~K}\right): \delta=0.73\left(\mathrm{~d}, 6 \mathrm{H},{ }^{3} J_{\mathrm{HH}}=6.8 \mathrm{~Hz}\right.$, Dipp-Pri $\left.\mathrm{CH}_{3}\right), 0.83\left(\mathrm{~d}, 6 \mathrm{H},{ }^{3} \mathrm{JHH}_{\mathrm{HH}}=7.4 \mathrm{~Hz}, \mathrm{Si}_{-} \mathrm{Pr}^{\mathrm{i}}-\mathrm{CH}_{3}\right), 0.94\left(\mathrm{~d}, 6 \mathrm{H},{ }^{3} J_{\mathrm{HH}}=7.4 \mathrm{~Hz}, \mathrm{Si}^{-} \mathrm{Pr}^{\mathrm{i}}-\right.$ $\left.\mathrm{CH}_{3}\right), 1.14\left(\mathrm{~d}, 6 \mathrm{H},{ }^{3} \mathrm{~J}_{\mathrm{HH}}=6.8 \mathrm{~Hz}\right.$, Dipp-Pri $\left.-\mathrm{CH}_{3}\right), 1.15\left(\mathrm{~d}, 12 \mathrm{H},{ }^{3} \mathrm{~J}_{\mathrm{HH}}=6.9 \mathrm{~Hz}\right.$, NHC-iPr- $\left.\mathrm{CH}_{3}\right) 1.28\left(\right.$ sept, $\left.2 \mathrm{H},{ }^{3} \mathrm{~J}_{\mathrm{HH}}=7.4 \mathrm{~Hz}, \mathrm{Si}-\mathrm{Pr} \mathrm{i}^{\mathrm{i}} \mathrm{CH}\right), 1.66(\mathrm{~d}, 2 \mathrm{H}$, $\left.{ }^{2} J_{\mathrm{PH}}=4.8 \mathrm{~Hz}, \mathrm{Ph}_{2} \mathrm{P}-\mathrm{CH}_{2}\right), 2.15$ (s, 6H, NHC-Me), 3.82 (sept, $2 \mathrm{H},{ }^{3} J_{\mathrm{HH}}=6.8 \mathrm{~Hz}$, Dipp-Pri-CH), 4.17 (br m, $1 \mathrm{H}, \mathrm{Be}-H), 4.80\left(\mathrm{sept}, 2 \mathrm{H},{ }^{3} \mathrm{~J}_{\mathrm{HH}}=6.9 \mathrm{~Hz}, \mathrm{NHC}-\mathrm{i} \mathrm{Pr}-\right.$ $\mathrm{CH}), 6.79$ (t, 1H, Dipp-p-CH), 6.94 (d, 2H, Dipp- $m-\mathrm{CH}), 7.12-7.23$ (m, $6 \mathrm{H}, \mathrm{Ar}-$ $\mathrm{CH}), 7.46-7.52(\mathrm{~m}, 4 \mathrm{H}, \mathrm{Ar}-\mathrm{CH})$

${ }^{13} \mathrm{C}\left\{{ }^{1} \mathrm{H}\right\}$ NMR $\left(\mathrm{C}_{6} \mathrm{D}_{6}, 101 \mathrm{MHz}, 298 \mathrm{~K}\right): \delta=9.9(\mathrm{NHC}-\mathrm{NCMe}), 13.2(\mathrm{~d}$, $\left.{ }^{1} J_{\mathrm{CP}}=32.5 \mathrm{~Hz}, \mathrm{Ph}_{2} \mathrm{P}-\mathrm{CH}_{2}\right), 16.2\left(\mathrm{~d},{ }^{3} J_{\mathrm{CP}}=2.5 \mathrm{~Hz}\right.$, Si- ${ }^{\mathrm{i} P r}-\mathrm{CH}$ ), 20.4 and 20.5 (Dipp$\left.{ }^{\mathrm{i}} \mathrm{Pr}-\mathrm{CH}_{3}\right), 21.5\left(\mathrm{Si}-{ }^{\mathrm{i}} \mathrm{Pr}-\mathrm{CH}_{3}\right), 25.3\left(\mathrm{NHC}-{ }^{\mathrm{i} P r}-\mathrm{CH}_{3}\right), 27.8$ (Dipp-i $\left.\mathrm{Pr}-\mathrm{CH}\right), 52.7$ (NHC-iPr-CH), 121.9 (NHC-NCMe), 124.2, 125.2, 125.7, 128.6, 129.3, 133.6 (d), 144.4 (d), 144.7, 151.9 (Ar-C), and 173.1 (NHC-C:).

${ }^{31} \mathbf{P}\left\{{ }^{1} \mathrm{H}\right\}$ NMR $\left(\mathrm{C}_{6} \mathrm{D}_{6}, 162 \mathrm{MHz}, 298 \mathrm{~K}\right): \delta=-21.1\left(\mathrm{~s},{ }^{1} \mathrm{Pr}_{2} \mathrm{P}-\mathrm{Be}\right)$.

${ }^{29} \mathrm{Si}\left\{{ }^{1} \mathrm{H}\right\}$ NMR $\left(\mathrm{C}_{6} \mathrm{D}_{6}, 99 \mathrm{MHz}, 298 \mathrm{~K}\right): \delta=-0.1\left(\mathrm{~d},{ }^{2} J_{\mathrm{SPP}}=15.5 \mathrm{~Hz}, \mathrm{Si}^{-}{ }^{\mathrm{i}} \mathrm{Pr}_{2}\right)$.

${ }^{9}$ Be NMR $\left(\mathrm{C}_{6} \mathrm{D}_{6}, 58 \mathrm{MHz}, 298 \mathrm{~K}\right), \delta=14.9$.

MS/LIFDI-HRMS found (calcd.) $\mathrm{m} / z$ : 678.4589 (678.4723) for $[\mathrm{M}]^{+}$.

IR, $v \mathrm{~cm}^{-1}$ (ATR): $1742(\mathrm{~m}, \mathrm{Be}-\mathrm{H}), 1800(\mathrm{w}, \mathrm{Be}-\mathrm{H})$

${ }_{[}^{\text {PhiPDippBeCO}(H) O ~}{ }_{2}$, 10. Compound $8(200 \mathrm{mg}, 0.20 \mathrm{mmol})$ was suspended in toluene $(5 \mathrm{~mL})$, and the Schlenk flask purged with dry $\mathrm{CO}_{2}$ through a septum, using a needle adapter. The flask was quickly sealed, and stirred for $16 \mathrm{~h}$, whereupon a clear, colourless solution had formed. Removal of the stir bar, concentration to $\sim 1 \mathrm{~mL}$, and layering with hexane $(5 \mathrm{~mL})$ led to the formation of a large crop of colourless crystals of $10(135 \mathrm{mg}, 63 \%)$.

${ }^{1} \mathrm{H}$ NMR $\left(\mathrm{C}_{6} \mathrm{D}_{6}, 400 \mathrm{MHz}, 298 \mathrm{~K}\right): \delta=0.81\left(\mathrm{~d}, 6 \mathrm{H}(\right.$ conf. $(a)),{ }^{3} J_{\mathrm{HH}}=6.8 \mathrm{~Hz}$, Dipp-Pri $-\mathrm{CH}_{3}$ ), 0.95 (overlapping d, $6 \mathrm{H}$ (conf. (a)) and 12H (conf. (b)), Dipp-Pri $\mathrm{CH}_{3}$ and $\mathrm{Si}-\mathrm{Pr}^{\mathrm{i}}-\mathrm{CH}_{3}$ ), 1.19 (overlapping d, $12 \mathrm{H}$ (conf. (a)) and $9 \mathrm{H}$ (conf. (b)), Dipp-Pri $-\mathrm{CH}_{3}$ and Si-Pri $\left.{ }^{\mathrm{i}}-\mathrm{CH}_{3}\right), 1.24$ (d, $3 \mathrm{H}$ (conf. $(b)$ ), ${ }^{3} J_{\mathrm{HH}}=6.8 \mathrm{~Hz}$, Dipp-Pri$\mathrm{CH}_{3}$ ), 1.16-1-31 (2H (conf. (a)) and 2H (conf. (b)), Si-Pri-CH), 1.52 (d, 2H (conf (b)), ${ }^{2} \mathrm{~J}_{\mathrm{PH}}=10.9 \mathrm{~Hz}, \mathrm{Ph}_{2} \mathrm{P}-\mathrm{CH}_{2}$ ), 1.52 (d, $2 \mathrm{H}$ (conf. $\left.(a)\right),{ }^{2} J_{\mathrm{PH}}=9.2 \mathrm{~Hz}, \mathrm{Ph}_{2} \mathrm{P}-\mathrm{CH}_{2}$ ), 3.67 (sept, $2 \mathrm{H}$ (conf. (a)), ${ }^{3} \mathrm{H}_{\mathrm{HH}}=6.8 \mathrm{~Hz}$, Dipp-Pri $-\mathrm{CH}$ ), 3.72 (sept, $2 \mathrm{H}$ (conf. (b)), ${ }^{3} J_{\mathrm{HH}}=6.8 \mathrm{~Hz}$, Dipp-Pri $-\mathrm{CH}$ ), 7.06 (overlapping $\mathrm{m}, 9 \mathrm{H}$ (conf. (a)) and $9 \mathrm{H}$ (conf. (b)), $\mathrm{Ar}-\mathrm{CH}$ ), 7.38 (m, $4 \mathrm{H}$ (conf. (b)), $\mathrm{Ar}-\mathrm{CH}$ ), 7.52 (m, 4H (conf. (b)), Ar-CH), 7.05-7.20 (m, 11H, Ar-CH), 7.69 (s, 1H ((conf. $(b)), \mathrm{Be}-\mathrm{OC}(\mathrm{H}) \mathrm{O}-\mathrm{Be}), 7.83(\mathrm{~s}, 1 \mathrm{H}$ (conf. (a)), Be-OC $(H) \mathrm{O}-\mathrm{Be}$ )

${ }^{13} \mathrm{C}\left\{{ }^{1} \mathrm{H}\right\}$ NMR $\left(\mathrm{C}_{6} \mathrm{D}_{6}, 101 \mathrm{MHz}, 298 \mathrm{~K}\right): \delta=6.3$ and $6.5\left(2 \times \mathrm{d},{ }^{1} J_{\mathrm{CP}}=8.6\right.$ and $\left.4.2 \mathrm{~Hz}, \mathrm{Ph}_{2} \mathrm{P}-\mathrm{CH}_{2}\right), 15.1$ and $15.4\left(2 \times \mathrm{d},{ }^{3} J_{\mathrm{CP}}=1.9\right.$ and $\left.2.5 \mathrm{~Hz}, \mathrm{Si}-{ }^{-} \mathrm{Pr}-\mathrm{CH}\right), 19.0$, $19.1,19.6$ and $19.8\left(\mathrm{Si}-\mathrm{Pr}-\mathrm{CH}_{3}\right), 23.9,24.0,24.7$, and $26.8\left(\mathrm{Dipp}-\mathrm{Pr}^{\mathrm{i}}-\mathrm{CH}_{3}\right), 27.5$ and 27.6 (Dipp-Pri-CH), 121.9, 122.5, 123.5, 123.8, 128.9 and 129.0 (overlapping d) $129.8,132.7$ (d), 132.9 (d), 135.2 (d), 136.2 (d), 146.2, 146.3, 147.8 (d), and 148.3(Ar-C), 166.8 and $172.0\left(2 \times \mathrm{t},{ }^{3} J_{\mathrm{CP}}=3.0\right.$ and $\left.3.1 \mathrm{~Hz}, \mathrm{Be}-\mathrm{OC}(\mathrm{H}) \mathrm{O}-\mathrm{Be}\right)$.

${ }^{31} \mathbf{P}\left\{{ }^{1} \mathrm{H}\right\}$ NMR $\left(\mathrm{C}_{6} \mathrm{D}_{6}, 162 \mathrm{MHz}, 298 \mathrm{~K}\right): \delta=-22.3\left(\mathrm{~s}, \mathrm{Ph}_{2} P-\mathrm{BeOC}(\mathrm{H}) \mathrm{O}\right.$, conf. (b)), and $-23.9\left(\mathrm{~s}, \mathrm{Ph}_{2} P-\mathrm{BeOC}(\mathrm{H}) \mathrm{O}\right.$, conf. (a)).

${ }^{29} \mathrm{Si}\left\{{ }^{1} \mathrm{H}\right\}$ NMR $\left(\mathrm{C}_{6} \mathrm{D}_{6}, 99 \mathrm{MHz}, 298 \mathrm{~K}\right): \delta=0.0\left(\mathrm{~d},{ }^{2} J_{\mathrm{SiP}}=4.5 \mathrm{~Hz}, \mathrm{iPr}_{2} \mathrm{Si}_{-} \mathrm{CH}_{2-}\right.$ $\mathrm{PPh}_{2}$, conf. (a)), $0.13\left(\mathrm{~d},{ }^{2} J_{\mathrm{SiP}}=4.7 \mathrm{~Hz}, \mathrm{PPr}_{2} \mathrm{Si}_{-}-\mathrm{CH}_{2}-\mathrm{PPh}_{2}\right.$, conf. (a))

${ }^{9}$ Be NMR $\left(\mathrm{C}_{6} \mathrm{D}_{6}, 58 \mathrm{MHz}, 298 \mathrm{~K}\right), \delta=3.5(\mathrm{v} \mathrm{br})$.

IR, $v \mathrm{~cm}^{-1}$ (ATR): $1650(\mathrm{~s}, \mathrm{Be}-O=C(\mathrm{H}) \mathrm{O})$

MS/LIFDI-HRMS found (calcd.) $\mathrm{m} / z: 1084.6012(1084.6001)$ for $\left[\mathrm{M}^{+}\right]$.

${ }_{[}$PhiP DippBeC(H)O] $]_{2}$, 11. Compound $6(300 \mathrm{mg}, 0.30 \mathrm{mmol})$ was suspended in toluene $(6 \mathrm{~mL})$, and the flask subjected to three freeze-pump-thaw cycles, backfilling with $\mathrm{CO}$ each time. The flask was subsequently sealed and stirred at ambient temperature for 2 days, at which stage a clear, colourless solution had formed. The reaction mixture was then filtered and layered with heptane $(15 \mathrm{~mL})$, leading to the formation of X-ray quality colourless crystals of 11 (105 mg, 33\%).

${ }^{1} \mathbf{H}$ NMR (D - THF, $\left.400 \mathrm{MHz}, 338 \mathrm{~K}\right): \delta=0.49\left(\mathrm{~m}, 12 \mathrm{H}, \mathrm{Si}-\mathrm{Pr}^{\mathrm{i}}-\mathrm{CH}_{3}\right), 0.78$ (overlapping d/sept, for d: ${ }^{3} J_{\mathrm{HH}}=7.4 \mathrm{~Hz}, 10 \mathrm{H}, \mathrm{Si}^{-} \mathrm{Pr}^{\mathrm{i}}-\mathrm{CH}_{3}$ and $\mathrm{Si}-\mathrm{Pr}{ }^{\mathrm{i}}-\mathrm{CH}$ ), 0.95 (overlapping d, $18 \mathrm{H}, \mathrm{Si}-\mathrm{Pr}^{\mathrm{i}}-\mathrm{CH}_{3}$ and Dipp-Pri $\left.-\mathrm{CH}_{3}\right), 1.10\left(\mathrm{~d}, 6 \mathrm{H},{ }^{3} J_{\mathrm{HH}}=6.8 \mathrm{~Hz}\right.$, Dipp-Pri $\left.-\mathrm{CH}_{3}\right), 1.38\left(\mathrm{br}, 6 \mathrm{H}\right.$, Dipp-Pri- $\left.\mathrm{CH}_{3}\right), 1.46\left(\mathrm{~m}, 2 \mathrm{H}, \mathrm{Ph}_{2} \mathrm{P}-\mathrm{CH}_{2}\right), 1.96(\mathrm{~d}, 2 \mathrm{H}$ 
$\mathrm{Ph}_{2} \mathrm{P}-\mathrm{CH}_{2}$ ), 2.86 (sept, $2 \mathrm{H},{ }^{3} J_{\mathrm{HH}}=6.8 \mathrm{~Hz}$, Dipp-Pri $-\mathrm{CH}$ ), 3.56 (br sept, $2 \mathrm{H}$, Dipp$\left.\mathrm{Pr}^{\mathrm{i}}-\mathrm{CH}\right), 4.86\left(\mathrm{~d}, 2 \mathrm{H},{ }^{2} J_{\mathrm{PH}}=12.0 \mathrm{~Hz}, \mathrm{Be}-\mathrm{C}(H) \mathrm{O}\right), 6.80-6.92(\mathrm{~m}, 6 \mathrm{H}, \mathrm{Ar}-\mathrm{CH})$, 7.06-7.14 (m, 3H, Ar-CH), 7.28-7.36 (m, 3H, Ar- $\mathrm{CH}$ ), 7.49-7.60 (m, 6H, Ar-CH), 7.94-8.0 (m, 4H, Ar-CH), 8.20-8.30 (m, 3H, Ar-CH).

${ }^{13} \mathrm{C}\left\{{ }^{1} \mathrm{H}\right\}$ NMR (D ${ }_{8}$-THF, $\left.101 \mathrm{MHz}, 298 \mathrm{~K}\right): \delta=2.4\left(\mathrm{~d},{ }^{1} J_{\mathrm{CP}}=44.0 \mathrm{~Hz}, \mathrm{Ph}_{2} \mathrm{P}-\right.$ $\left.\mathrm{CH}_{2}\right), 15.8$ and $16.2\left(\mathrm{Si}-{ }^{\mathrm{i}} \mathrm{Pr}-\mathrm{CH}\right), 18.7,19.4,19.7$, and $20.3\left(\mathrm{Si}-{ }^{-} \mathrm{Pr}-\mathrm{CH}_{3}\right), 24.0$, and 24.1 (Dipp-Pri-CH), 26.0, 26.88, 27.9, and 28.6 (Dipp-Pri $\left.-\mathrm{CH}_{3}\right), 63.3(\mathrm{Be}-\mathrm{C}(\mathrm{H}) \mathrm{O}$, $\left.{ }^{1} J_{\mathrm{CP}}=21.0 \mathrm{~Hz}\right), 121.6,122.8,123.46,129.2,129.3,129.4,129.9$ (d), 131.9, 132.4, 132.9 (d), 133.5, 133.6, 145.5, 146.5, and $148.8(\mathrm{Ar}-\mathrm{C})$.

${ }^{31} \mathbf{P}\left\{{ }^{1} \mathrm{H}\right\}$ NMR $\left(\mathrm{D}_{8}\right.$-THF, $\left.162 \mathrm{MHz}, 298 \mathrm{~K}\right): \delta=9.5\left(\right.$ br s, $\left.\mathrm{Ph}_{2} \mathrm{P}-\mathrm{Be}\right)$.

${ }^{9}$ Be NMR (D - THF, $\left.58 \mathrm{MHz}, 298 \mathrm{~K}\right), \delta=10.0$.

MS/LIFDI-HRMS found (calcd.) $\mathrm{m} / z$ : 1052.6149 (1052.6103) for $[\mathrm{M}]^{+}$.

N.B. Presumably due to broadening alongside the low solubility of $\mathbf{1 1}$, meaningful ${ }^{29} \mathrm{Si}$ NMR spectra could not be acquired.

[iPPh DippBeC(H)O $]_{2}, \mathbf{1 2}$. Compound $\mathbf{8}(150 \mathrm{mg}, 0.15 \mathrm{mmol})$ was dissolved in THF $(5 \mathrm{~mL})$, and the flask subjected to three freeze-pump-thaw cycles, backfilling with $\mathrm{CO}$ each time. The reaction mixture was then stirred at ambient temperature for 2 days, and all volatiles subsequently removed in vacuo. The residue was redissolved in $\mathrm{Et}_{2} \mathrm{O}$, filtered, and kept at ambient temperature for 3 days, leading to the formation of large colourless block-shaped crystals of 12 (65 mg, 41\%), suitable for X-ray crystallographic analysis.

${ }^{1} \mathbf{H}$ NMR (D - THF, $\left.400 \mathrm{MHz}, 298 \mathrm{~K}\right): \delta=-0.32\left(\mathrm{~m}, 2 \mathrm{H},{ }^{\mathrm{i}} \mathrm{Pr}_{2} \mathrm{P}-\mathrm{CH}_{2}-\mathrm{Be}\right), 0.02$ $\left(\mathrm{m}, 2 \mathrm{H},{ }^{\mathrm{i}} \mathrm{Pr}_{2} \mathrm{P}-\mathrm{CH}_{2}-\mathrm{Be}\right), 0.26\left(\mathrm{~d}, 6 \mathrm{H},{ }^{3} \mathrm{~J}_{\mathrm{HH}}=6.8 \mathrm{~Hz}, \mathrm{Dipp}-\mathrm{Pr}^{\mathrm{i}}-\mathrm{CH}_{3}\right), 0.52(\mathrm{~d}, 3 \mathrm{H}$, $\left.{ }^{3} J_{\mathrm{HH}}=7.2 \mathrm{~Hz}, \mathrm{P}-\mathrm{Pr}^{\mathrm{i}}-\mathrm{CH}_{3}\right), 0.55\left(\mathrm{~d}, 3 \mathrm{H},{ }^{3} J_{\mathrm{HH}}=7.2 \mathrm{~Hz}, \mathrm{P}-\mathrm{Pr}^{\mathrm{i}}-\mathrm{CH}_{3}\right), 0.68(\mathrm{~d}, 3 \mathrm{H}$, $\left.{ }^{3} J_{\mathrm{HH}}=7.2 \mathrm{~Hz}, \mathrm{P}-\mathrm{Pr}^{\mathrm{i}}-\mathrm{CH}_{3}\right), 0.72\left(\mathrm{~d}, 3 \mathrm{H},{ }^{3} J_{\mathrm{HH}}=7.2 \mathrm{~Hz}, \mathrm{P}-\mathrm{Pr}^{\mathrm{i}}-\mathrm{CH}_{3}\right), 0.81-0.89$ (overlapping d, 12H, P-Pri $-\mathrm{CH}_{3}$ and Dipp-Pri $\left.-\mathrm{CH}_{3}\right), 0.93\left(\mathrm{~d}, 6 \mathrm{H},{ }^{3} \mathrm{JHH}_{\mathrm{HH}}=6.8 \mathrm{~Hz}\right.$ Dipp-Pri $\left.-\mathrm{CH}_{3}\right), 1.04\left(\mathrm{~d}, 3 \mathrm{H},{ }^{3} J_{\mathrm{HH}}=7.2 \mathrm{~Hz}, \mathrm{P}-\mathrm{Pr}^{\mathrm{i}}-\mathrm{CH}_{3}\right), 1.07\left(\mathrm{~d}, 3 \mathrm{H},{ }^{3} J_{\mathrm{HH}}=7.2 \mathrm{~Hz}\right.$, P-Pri $-\mathrm{CH}_{3}$ ), $1.42\left(\right.$ sept, $\left.2 \mathrm{H},{ }^{3} J_{\mathrm{HH}}=7.2 \mathrm{~Hz}, \mathrm{P}-\mathrm{Pr}^{\mathrm{i}}-\mathrm{CH}\right), 1.75$ (overlapping sept, $2 \mathrm{H}$, P-Pri $-\mathrm{CH}$ ), 3.31 (sept, $2 \mathrm{H},{ }^{3} \mathrm{~J}_{\mathrm{HH}}=6.8 \mathrm{~Hz}$, Dipp-Pri-CH), 4.20 (sept, $2 \mathrm{H}$,

${ }^{3} J_{\mathrm{HH}}=6.8 \mathrm{~Hz}$, Dipp-Pri $\left.{ }^{\mathrm{i}}-\mathrm{CH}\right), 4.77\left(\mathrm{~d}, 2 \mathrm{H},{ }^{2} J_{\mathrm{PH}}=8.4 \mathrm{~Hz}, \mathrm{BeOC}(H) \mathrm{P}\right), 6.72(\mathrm{~m}, 2 \mathrm{H}$, Ar-CH), 6.80 (m, 2H, Ar-CH), 6.97 (m, 2H, Ar- $\mathrm{CH}), 7.27$ (m, 10H, Ar-CH), 7.31 (m, 2H, Ar-CH), $7.74(\mathrm{~m}, 8 \mathrm{H}, \mathrm{Ar}-\mathrm{CH})$.

${ }^{13} \mathrm{C}\left\{{ }^{1} \mathrm{H}\right\}$ NMR (D ${ }_{8}$-THF, $\left.101 \mathrm{MHz}, 298 \mathrm{~K}\right): \delta=17.5\left(\mathrm{~d},{ }^{1} J_{\mathrm{CP}}=15.0 \mathrm{~Hz},{ }^{1} \mathrm{Pr}_{2} \mathrm{P}-\right.$ $\left.\mathrm{CH}_{2}\right), 18.7$ and $19.6\left({ }^{\mathrm{i}} \mathrm{Pr}_{2} \mathrm{P}-\mathrm{P} \mathrm{Pr}-\mathrm{CH}_{3}\right), 24.5$ and $24.9\left(\mathrm{Dipp}-\mathrm{P} \mathrm{Pr}^{-} \mathrm{CH}_{3}\right), 26.8$ and 27.7 (Dipp-i $\mathrm{Pr}-\mathrm{CH}$ ), 28.3 and 28.5 ( $\left.{ }^{\mathrm{P} r}{ }_{2} \mathrm{P}-\mathrm{i} \mathrm{Pr}-\mathrm{CH}\right), 120.9,124.1$ (d), 127.9 (d), 129.4, $130.2,136.3,138.2,146.0$, and $150.8(A r-C)$.

${ }^{31} \mathbf{P}\left\{{ }^{1} \mathrm{H}\right\}$ NMR $\left(\mathrm{D}_{8}\right.$-THF, $\left.162 \mathrm{MHz}, 298 \mathrm{~K}\right): \delta=62.5$ (s, $\left.{ }^{\mathrm{i}} \mathrm{Pr}_{2} \mathrm{P}-\mathrm{CO}\right)$.

${ }^{29} \mathrm{Si}\left\{{ }^{1} \mathbf{H}\right\}$ NMR (D - THF, $\left.99 \mathrm{MHz}, 298 \mathrm{~K}\right): \delta=-28.0$.

${ }^{9}$ Be NMR ( ${ }_{8}$-THF, $58 \mathrm{MHz}, 298 \mathrm{~K}$ ), $\delta=8.2$.

MS/LIFDI-HRMS found (calcd.) $\mathrm{m} / z: 1052.6117$ (1052.6103) for [M] ${ }^{+}$.

\section{Data availability}

Crystallographic Information Files have been deposited in the Cambridge Crystallographic Data Centre (deposition numbers: 2101682-2101690) and can be accessed free of charge from The Cambridge Crystallographic Data Centre via www.ccdc.cam.ac.uk/data_request/cif. All information supporting the findings in this study are available either within the article, its Supplementary Information, or are available from the corresponding author upon reasonable request.

Received: 3 September 2021; Accepted: 10 January 2022; Published online: 24 January 2022

\section{References}

1. Davis, B. H. \& Occelli, M. L. (eds) Advances in Fischer-Tropsch Synthesis Catalysts and Catalysis (CRC, 2009).

2. Khodakov, A. Y., Chu, W. \& Fongarland, P. Advances in the development of novel cobalt Fischer-Tropsch catalysts for synthesis of long-chain hydrocarbons and clean fuels. Chem. Rev. 107, 1692-1744 (2007).

3. Franke, R., Selent, D. \& Armin Börner, A. Applied hydroformylation. Chem. Rev. 112, 5675-5732 (2012).

4. Clarke, M. L. (ed.) Hydroformylation. Fundamentals, Processes, and Applications in Organic Synthesis (Wiley-VCH, 2016).

5. Ricker, J. D. \& Geary, L. M. Recent advances in the Pauson-Khand reaction. Top. Catal. 60, 609-619 (2017).

6. Blanco-Urgoiti, J., Añorbe, L., Pérez-Serrano, L., Domínguez, G. \& PérezCastells, J. The Pauson-Khand reaction, a powerful synthetic tool for the synthesis of complex molecules. Chem. Soc. Rev. 33, 32-42 (2004).

7. Katahira, D. A., Moloy, K. G. \& Marks, T. J. Carbon monoxide activation by organoactinides. Formyl pathways in CO homologation and hydrogenation. Organometallics 1, 1723-1726 (1982).

8. Evans, W. J., Grate, J. W. \& Doedens, R. J. Organolanthanide and organoyttrium hydride chemistry. 7. Reaction of the samarium-hydrogen bond in the organosamarium hydride $\left[\left(\mathrm{C}_{5} \mathrm{Me}_{5}\right)_{2} \mathrm{SmH}\right]_{2}$ with carbon monoxide: formation, isomerization, and $\mathrm{X}$-ray crystallographic characterization of the samarium complexes cis- and trans-
$\left\{\left(\mathrm{C}_{5} \mathrm{Me}_{5}\right)_{2}\left[\left(\mathrm{C}_{6} \mathrm{H}_{5}\right)_{3} \mathrm{PO}\right] \mathrm{Sm}\right\}_{2}(\mu-\mathrm{OCH}: \mathrm{CHO})$. J. Am. Chem. Soc 107, 1671-1679 (1985).

9. Ferrence, G. M., McDonald, R. \& Takats, J. Stabilization of a discrete Lanthanide(II) hydrido complex by a bulky hydrotris(pyrazolyl)borate ligand. Angew. Chem. Int. Ed. 38, 2233-2237 (1999).

10. Shima, T. \& Hou, Z. Hydrogenation of carbon monoxide by tetranuclear rare earth metal polyhydrido complexes. selective formation of ethylene and isolation of well-defined polyoxo rare earth metal clusters. J. Am. Chem. Soc. 128, 8124-8125 (2006).

11. Cheng, J., Ferguson, M. J. \& Takats, J. Synthesis and reaction of $\left[\left(\mathrm{Tp}^{\mathrm{i}} \mathrm{Pr}_{2}\right)\right.$ $\left.\mathrm{LnH}_{2}\right]_{3}(\mathrm{Ln}=\mathrm{Y}, \mathrm{Lu})$ with CO: trinuclear cluster-bound propenolate en route to selective formation of propene. J. Am. Chem. Soc. 132, 2-3 (2010).

12. Erker, G. Carbonylation of zirconocene complexes. Acc. Chem. Res. 17, 103-109 (1984).

13. Werkema, E. L., Maron, L., Eisenstein, O. \& Andersen, R. A. Reactions of monomeric $\left[1,2,4-\left(\mathrm{Me}_{3} \mathrm{C}\right)_{3} \mathrm{C}_{5} \mathrm{H}_{2}\right]_{2} \mathrm{CeH}$ and $\mathrm{CO}$ with or without $\mathrm{H}_{2}$ : an experimental and Computational Study. J. Am. Chem. Soc. 129, 2529-2541 (2007).

14. Falcone, M., Scopelliti, R. \& Mazzanti, M. $\mathrm{CO}_{2}$ and $\mathrm{CO} / \mathrm{H}_{2}$ conversion to methoxide by a uranium(IV) hydride. J. Am. Chem. Soc. 141, 9570-9577 (2019).

15. Lalrempuia, R. et al. Activation of $\mathrm{CO}$ by hydrogenated magnesium(I) dimers: sterically controlled formation of ethenediolate and cyclopropanetriolate complexes. J. Am. Chem. Soc. 2015, 8944-8947 (2015). 137.

16. Anker, M. D., Hill, M. S., Lowe, J. P. \& Mahon, M. F. Alkaline-earth-promoted CO homologation and reductive catalysis. Angew. Chem. Int. Ed. 54, 10009-10011 (2015).

17. Anker, M. D. et al. Alkaline earth-centered CO homologation, reduction, and amine carbonylation. J. Am. Chem. Soc. 139, 10036-10054 (2017).

18. Harder, S. Molecular early main group metal hydrides: synthetic challenge, structures and applications. Chem. Commun. 48, 11165-11177 (2012).

19. Smith, G. S. et al. The crystal and molecular structure of beryllium hydride. Solid State Commun. 67, 491-494 (1988).

20. Han, R. \& Parkin, G. [Tris(3-tert-butylpyrazolyl)hydroborato]beryllium hydride: synthesis, structure, and reactivity of a terminal beryllium hydride complex. Inorg. Chem. 31, 983-988 (1992).

21. Arrowsmith, M., Hill, M. S., Kociok-Köhn, G., MacDougall, D. J. \& Mahon, M. F. Beryllium-induced C-N bond activation and ring opening of an Nheterocyclic carbene. Angew. Chem. Int. Ed. 51, 2098-2100 (2012).

22. Arrowsmith, M., Hill, M. S. \& Kociok-Köhn, G. Activation of N-heterocyclic carbenes by $\left\{\mathrm{BeH}_{2}\right\}$ and $\{\mathrm{Be}(\mathrm{H})(\mathrm{Me})\}$ fragments. Organometallics 34, 653-662 (2015).

23. Paparo, A. et al. N-Heterocyclic carbene, carbodiphosphorane and diphosphine adducts of beryllium dihalides: synthesis, characterisation and reduction studies. Dalton Trans. 50, 7604-7609 (2020).

24. Iversen, K. J., Wilson, D. J. D. \& Dutton, J. L. Comparison of the mechanism of borane, silane, and beryllium hydride ring insertion into N-heterocyclic carbene C $-\mathrm{N}$ bonds: a Computational Study. Organometallics 32, 6209-6217 (2013).

25. Strupp, C. Beryllium metal II. A review of the available toxicity data. Ann. Occup. Hyg. 55, 43-56 (2011).

26. Naglav, D., Buchner, M., Bendt, G., Kraus, F. \& Schulz, S. Off the beaten track -a Hitchhiker's guide to beryllium chemistry. Angew. Chem. Int. Ed. 55, 10562-10576 (2016).

27. Keil, P. M., Szilvási, T. \& Hadlington, T. J. Reversible metathesis of ammonia in an acyclic germylene-Ni ${ }^{0}$ complex. Chem. Sci. 12, 5582-5590 (2021).

28. Paparo, A. \& Jones, C. Beryllium halide complexes incorporating neutral or anionic ligands: potential precursors for beryllium chemistry. Chem. Asian J. 14, 486-490 (2019).

29. Harder, S. \& Brettar, J. Rational design of a well-defined soluble calcium hydride complex. Angew. Chem. Int. Ed. 45, 3474-3478 (2006).

30. Pécharman, A.-F., Hill, M. S. \& Mahon, M. F. Diborane heterolysis: breaking and making B-B bonds at magnesium. Dalton Trans. 47, 7300-7305 (2018).

31. Jones, D. D. L., Matthews, A. J. R. \& Jones, C. The complex reactivity of $\beta$ diketiminato magnesium(I) dimers towards pinacolborane: implications for catalysis. Dalton Trans. 48, 5785-5792 (2019).

32. Revunova, K. \& Nikonov, G. I. Base-catalyzed hydrosilylation of ketones and esters and insight into the mechanism. Chem. Eur. J. 20, 839-845 (2013).

33. Arrowsmith, M. et al. Three-coordinate beryllium $\beta$-diketiminates: synthesis and reduction chemistry. Inorg. Chem. 51, 13408-13418 (2012).

34. Anker, M. D. et al. Selective reduction of $\mathrm{CO}_{2}$ to a methanol equivalent by $\mathrm{B}\left(\mathrm{C}_{6} \mathrm{~F}_{5}\right)_{3}$-activated alkaline earth catalysis. Chem. Sci. 5, 2826-2830 (2014).

35. Schnitzler, S., Spaniol, T. P. \& Okuda, J. Reactivity of a molecular magnesium hydride featuring a terminal magnesium-hydrogen bond. Inorg. Chem. 55, 12997-13006 (2016).

36. Chi, C. et al. Alkali metal covalent bonding in nickel carbonyl complexes $\mathrm{ENi}(\mathrm{CO})_{3}{ }^{-}$. Angew. Chem. Int. Ed. 58, 1732-1738 (2019).

37. Wang, G. et al. s-Block multiple bonds: isolation of a beryllium imido complex. Angew. Chem. Int. Ed. 60, 9407-9411 (2021). 
38. Dutton, J. L. \& Wilson, D. J. D. Theoretical predictions of aromatic Be-O rings. Dalton Trans. 47, 12633-12641 (2018).

39. Patton, J. T., Bokota, M. M. \& Abboud, K. A. Indium-bridged chelating diamide Group IV metal olefin polymerization catalysts. Organometallics 21, 2145-2148 (2002).

40. Eisenträger, F. et al. Sterically crowded diphosphinomethaneligands: molecular structures, UV-photoelectron spectroscopy and a convenient general synthesis of ${ }^{\mathrm{t}} \mathrm{Bu}_{2} \mathrm{PCH}_{2} \mathrm{P}^{\mathrm{t}} \mathrm{Bu}_{2}$ and related species. New J. Chem. 27, 540-550 (2003).

41. Bailey, P. J. et al. The first structural characterisation of a Group 2 metal alkylperoxide complex: comments on the cleavage of dioxygen by magnesium alkyl complexes. Chem. Eur. J. 9, 4820-4828 (2003).

42. Dehnicke, K. \& Neumüller, B. Neues aus der Chemie des Berylliums. Z. Anorg. Allg. Chem. 634, 2703-2728 (2008).

\section{Acknowledgements}

T.J.H. is grateful for the receipt of a Liebig Stipendium of the Fonds der Chemischen Industrie, and for the receipt of funding from the Technical University Munich as a TUM Junior Fellow. He would also like to thank Prof. F. Krauss and Dr. M. Buchner for the generous gift of elemental beryllium, P. Keil for aiding in the measurement of LIFDIMS and IR spectra, and C. Fajman and T. Restle for aiding in running and analysing Power X-ray diffraction experiments. T.S. thanks the University of Alabama and the Office of Information Technology for providing high performance computing resources and support. This computational work was made possible in part by a grant of highperformance computing resources and technical support from the Alabama Supercomputer Authority.

\section{Author contributions}

T.J.H. designed and planned the project, and carried out all experimental work. T.S. performed computational investigations.

\section{Funding}

Open Access funding enabled and organized by Projekt DEAL.

\section{Competing interests}

The authors declare no competing interests.

\section{Additional information}

Supplementary information The online version contains supplementary material available at https://doi.org/10.1038/s41467-022-28095-0.

Correspondence and requests for materials should be addressed to Terrance J. Hadlington.

Peer review information Nature Communications thanks the anonymous reviewer(s) for their contribution to the peer review of this work. Peer reviewer reports are available.

Reprints and permission information is available at http://www.nature.com/reprints

Publisher's note Springer Nature remains neutral with regard to jurisdictional claims in published maps and institutional affiliations.

\section{(c) (i)}

Open Access This article is licensed under a Creative Commons Attribution 4.0 International License, which permits use, sharing, adaptation, distribution and reproduction in any medium or format, as long as you give appropriate credit to the original author(s) and the source, provide a link to the Creative Commons license, and indicate if changes were made. The images or other third party material in this article are included in the article's Creative Commons license, unless indicated otherwise in a credit line to the material. If material is not included in the article's Creative Commons license and your intended use is not permitted by statutory regulation or exceeds the permitted use, you will need to obtain permission directly from the copyright holder. To view a copy of this license, visit http://creativecommons.org/ licenses/by/4.0/.

(C) The Author(s) 2022 